\title{
The NICE COVID-19 search strategy for Ovid MEDLINE and Embase: developing and maintaining a strategy to support rapid guidelines
}

\section{Authors}

Paul Levay https://orcid.org/0000-0003-1784-3314

Amy Finnegan https://orcid.org/0000-0002-7632-8956

\section{Affiliation}

National Institute for Health and Care Excellence (NICE), UK

\section{Address for correspondence}

\section{paul.levay@nice.org.uk}

NICE, Level 1A, City Tower, Manchester, M1 4BT, United Kingdom.

\section{Authors' contributions}

The authors contributed equally to the study design, data collection, analysis and writing of this manuscript.

\section{Competing interests}

Both authors have completed the ICMJE uniform disclosure form at www.icmje.org/coi disclosure.pdf and declare: no support from any organization for the submitted work; no financial relationships with any organizations that might have an interest in the submitted work in the previous three years; no other relationships or activities that could appear to have influenced the submitted work.

\section{Source of funding statement}

This study was conducted as part of the authors' employment at NICE and no additional funding was received. 
medRxiv preprint doi: https://doi.org/10.1101/2021.06.11.21258749; this version posted June 14, 2021. The copyright holder for this preprint (which was not certified by peer review) is the author/funder, who has granted medRxiv a license to display the preprint in perpetuity.

It is made available under a CC-BY 4.0 International license .

\section{Acknowledgements}

The authors would like to thank Caroline De Brún and Nicola Pearce-Smith from Public Health England for the original search terms and for helpful comments on the various versions of the strategy.

\section{Use of NICE COVID-19 content internationally}

Our COVID-19 rapid guidelines and evidence summaries are exempt from our overseas reuse application, licence and fee. This means you can:

- adopt the guidelines for your own healthcare setting

- adapt the guidelines by combining them with your own local content

- translate the resultant outputs.

When using content from our COVID-19 rapid guidelines and evidence summaries you must:

- make all your outputs reusing NICE content freely available to others

- acknowledge the use of NICE content, and link to the source content on our website

- only use the NICE logo if the original NICE guidance publication is used in its entirety without including additional content

- tell us how our content has been used by emailing reuseofcontent@nice.org.uk, to support the evaluation and development of our guidance.

We cannot accept responsibility or liability for the use of our content in third party outputs.

Further information on reuse of content is available on the NICE website. 
medRxiv preprint doi: https://doi.org/10.1101/2021.06.11.21258749; this version posted June 14, 2021. The copyright holder for this preprint (which was not certified by peer review) is the author/funder, who has granted medRxiv a license to display the preprint in perpetuity.

\section{Abstract \\ Introduction}

The United Kingdom's (UK) National Institute for Health and Care Excellence (NICE) needs access to evidence on COVID-19 to develop rapid guidelines for healthcare professionals. This paper reports on how the NICE COVID-19 search strategy for identifying references in Ovid MEDLINE and Embase has been developed and maintained.

Methods

Each free-text line from the June 2020 version of the NICE COVID-19 search strategy was categorised as Critical, High, Medium, Low or Zero priority, according to the number of results and their relevance to NICE. Five search options were devised and tested by combining them with a search for drug treatments. The two prioritised options were compared to the COVID-19 Limit available in Ovid. New subject headings were tested and added. The selected option was refined to make the strategy simpler to use.

Results

The updated strategy combines free-text terms, categorised as Critical, High and Medium priority for NICE, with appropriate subject headings.

\section{Discussion}

The paper describes the challenges of maintaining a search strategy during the COVID-19 pandemic, as terminology continues to evolve.

\section{Conclusions}

A search strategy for identifying COVID-19 references, within the remit of NICE, has been developed. The recommended strategy could be considered for validation at an appropriate point in the pandemic. It is hoped that understanding how NICE has maintained its COVID-19 strategy will encourage further discussion on the challenges. 
medRxiv preprint doi: https://doi.org/10.1101/2021.06.11.21258749; this version posted June 14, 2021. The copyright holder for this preprint (which was not certified by peer review) is the author/funder, who has granted medRxiv a license to display the preprint in perpetuity.

\section{Introduction}

\section{NICE COVID-19 rapid guidelines}

The United Kingdom's (UK) National Institute for Health and Care Excellence (NICE) uses the best available evidence to develop recommendations on a range of health and social care topics (NICE, 2020c). In March 2020, NICE was given responsibility for developing a series of products on COVID-19, including rapid guidelines. NICE had published 24 rapid guidelines by January 2021 (NICE, 2021). The rapid guidelines focused on managing symptoms and complications, therapeutics, clinically vulnerable conditions and managing health services during the pandemic (Southall, Taske, Power, Desai, \& Baillie, 2021).

To develop and maintain these guidelines, NICE needs access to evidence. One of the ways to identify evidence is to search a database. This paper describes how a search strategy has been updated to ensure it identifies COVID-19 references from MEDLINE and Embase using the Ovid platform.

\section{Purpose of the paper}

The purpose of this paper is to provide information specialists and other expert searchers with a detailed description of how the NICE COVID-19 search strategy has been developed and maintained. Search strategies need to be adapted as the COVID-19 pandemic progresses and the information landscape develops. Search strategies developed when the condition and virus did not even have names in early 2020 need to be updated to ensure they are appropriate to later stages of the pandemic. It is unclear, in May 2021, how the pandemic will develop and whether any further adjustments will have to be made to ensure search strategies remain appropriate.

It is important to emphasise that the search strategy has been developed to support the NICE remit of managing symptoms, therapeutics, vulnerable conditions, and managing services. The strategy has not been tested for coverage of aspects of the COVID-19 pandemic that are outside of the NICE remit (e.g. vaccinations or serological testing). 
medRxiv preprint doi: https://doi.org/10.1101/2021.06.11.21258749; this version posted June 14, 2021. The copyright holder for this preprint (which was not certified by peer review) is the author/funder, who has granted medRxiv a license to display the preprint in perpetuity.

It is made available under a CC-BY 4.0 International license .

The NICE COVID-19 strategy has not been validated and this is not intended to be a definitive search strategy. This strategy could be tailored by other organisations to suit their information needs. The purpose of this paper is to demonstrate the steps NICE has undertaken to ensure that the strategy is up to date. This paper also describes the technical challenges to searching for COVID-19. It is unusual to describe the development process in such detail, showing how a strategy has evolved, rather than just presenting the final strategy. The issues discussed in this paper will be faced by all systematic searches on COVID-19. It is hoped that understanding how NICE has approached these issues will encourage further discussion. Once these issues have been resolved, the strategy could be validated and used as a search filter. Suggestions for further iterations of the strategy are encouraged, as are any opportunities to collaborate on an overarching COVID-19 search filter.

\section{Literature searching process for NICE COVID-19 rapid guidelines}

Literature searches for the NICE rapid guidelines are conducted according to the methods manuals for guidelines (NICE, 2020c) and health and social care emergencies (NICE, 2020b). The searches are undertaken in a range of sources, such as: MEDLINE and Embase (Ovid), the Cochrane COVID-19 Study Register (https://covid-19.cochrane.org) and NICE Evidence Search (https://www.evidence.nhs.uk). Using a wide range of sources, including some specific to COVID-19, enables NICE to use a more specific search strategy in MEDLINE and Embase.

As well as producing the rapid guidelines, NICE has maintained them by monitoring all new COVID-19 references added to MEDLINE ALL, Embase and a range of other databases and websites since 16 March 2020 (NICE, 2020 b, section 17). These searches are run on a weekly basis so that NICE can capture the new references and assess whether any updates to the published rapid guidelines are necessary. By 9 March 2021, NICE had processed nearly 503,000 references from all sources, including approximately 332,000 from MEDLINE and 100,000 from Embase. These weekly searches are referred to as the 'Surveillance process', outlined below. 
medRxiv preprint doi: https://doi.org/10.1101/2021.06.11.21258749; this version posted June 14, 2021. The copyright holder for this preprint (which was not certified by peer review) is the author/funder, who has granted medRxiv a license to display the preprint in perpetuity.

It is made available under a CC-BY 4.0 International license .

\section{Developing the baseline NICE COVID-19 strategy}

NICE began work on the COVID-19 rapid guidelines on 16 March 2020 and published the first three on 20 March 2020 (NICE, 2021). It was essential to develop specific search strategies that could be used easily under urgent time constraints. Searches for the rapid guidelines would be written, tested, peer reviewed and performed in a single day, compared to the standard NICE guideline process spanning several weeks.

Version 1 of the NICE COVID-19 search strategy was developed on 16 March 2020 from a list of terms (see Appendix A) developed by Public Health England (PHE) Knowledge and Library Services (Public Health England, 2021). This incorporated a variety of terms for the virus and condition that had been used in January 2020, such as novel coronavirus and nCoV (Tian et al., 2020). The strategy was continually developed over the subsequent weeks, as the evidence changed, new ideas emerged, and naming conventions were established. Appendix B provides a brief overview of the modifications made with each version. The strategy was peer reviewed by a NICE information specialist at each stage. Appendix $C$ shows the terms that were removed from version 8 as they had not been used in the literature, such as "Ncorona". By June 2020, NICE had developed version 9 (see Strategy A in Appendix D) and this is the baseline strategy for testing in this paper.

\section{Changes to the information landscape}

The information landscape on COVID-19 has changed since March 2020. The volume of evidence has increased (Teixeira da Silva, Tsigaris, \&

Erfanmanesh, 2021). Terminology has been standardised since the World Health Organization (WHO) named the condition COVID-19 and the virus SARS-CoV-2 in February 2020 (World Health Organization, 2020). The National Library for Medicine has expanded Medical Subject Headings (MeSH) to include new specific terms, such as "COVID-19" (National Library of Medicine, 2020). The Emtree subject headings for Embase have also been updated (Elsevier, 2021). In Ovid, updates to MeSH were available from February 2021 and to Emtree from April 2021. The NICE search strategy from June 2020 needed to be updated to account for these changes. 
medRxiv preprint doi: https://doi.org/10.1101/2021.06.11.21258749; this version posted June 14, 2021. The copyright holder for this preprint (which was not certified by peer review) is the author/funder, who has granted medRxiv a license to display the preprint in perpetuity.

\section{Other COVID-19 strategies}

There are a number of search strategies available for finding evidence on COVID-19. Lazarus et al. (2020) compared eight different COVID-19 search strategies. However, these were designed for PubMed (rather than Ovid) and only covered references published from 11 March to 19 May 2020. The most sensitive strategy in the comparison (Shokraneh \& Russell-Rose, 2020) sets the benchmark against which other strategies should be measured, achieving a sensitivity of $98.7 \%$.

\section{Aims and objectives}

The purpose of this paper is to show how the NICE COVID-19 search strategy has been developed and maintained and to describe the challenges of searching at this point in the pandemic (May 2021).

The aims for NICE when developing the latest updates to the NICE COVID-19 search strategy for Ovid MEDLINE and Embase were to simplify the strategy and increase its specificity.

The objectives for NICE during the development period from December 2020 to May 2021 were to:

- Analyse the value of each free-text line used in version 9 of the NICE search strategy.

- Create various search strategy options, according to the contribution of each free-text line.

- Test the recall of the search strategy options.

- Refine the free-text terms used in the chosen option.

- Select appropriate subject headings for the final strategy.

- Consider the complexity and ease of use of the chosen option. 
medRxiv preprint doi: https://doi.org/10.1101/2021.06.11.21258749; this version posted June 14, 2021. The copyright holder for this preprint (which was not certified by peer review) is the author/funder, who has granted medRxiv a license to display the preprint in perpetuity.

\section{Methods}

\section{Purpose of updating the strategy}

A series of iterative steps were undertaken to check if the NICE COVID-19 strategy could be updated. The purpose of each step was to improve the specificity of the strategy, which measures the number of references that are not relevant and are not retrieved as a proportion of the total number of references not relevant (Jenkins, 2004). In other words, any amendments to reduce the number of results retrieved by the strategy should only remove references not relevant to NICE. This was done alongside changes that would make the strategy easier to use.

\section{Developing the baseline strategy}

The MEDLINE and Embase strategies were developed separately so that they were optimised for each database.

Appendix B provides a brief overview describing how versions 1-8 were developed from March to June 2020. The full MEDLINE strategies are presented in supplementary File A. Appendix C provides the results of a test that was run in May 2020 on the individual free-text terms contained in version 8. This resulted in several redundant terms being removed and the creation of version 9 in June 2020. The MEDLINE and Embase strategies used the same free-text terms, and the MeSH subject headings were mapped to Emtree.

\section{Search volume from each free-text line}

The testing was done in stages from December 2020 to April 2021. MEDLINE ALL and Embase (from 1974) were used throughout testing. The specific dates of the Ovid segment used are recorded in the title of the tables. The full search strategies for both databases are available in the supplementary information (File A for MEDLINE and File B for Embase).

The baseline strategy was run in December 2020 and the number of results from each of the 23 free-text lines was recorded. Individual terms were not tested. Instead, appropriate variations of a term were included, for example "SARSCoV2" and "SARS-CoV-2". Including free-text variants reflects 
medRxiv preprint doi: https://doi.org/10.1101/2021.06.11.21258749; this version posted June 14, 2021. The copyright holder for this preprint (which was not certified by peer review) is the author/funder, who has granted medRxiv a license to display the preprint in perpetuity.

It is made available under a CC-BY 4.0 International license .

searching practice, for example in the guide to peer reviewing strategies (McGowan et al., 2016). Individual terms were refined at a later stage.

\section{Relevant references from each free-text line}

The next stage recorded the unique contribution from each of the 23 free-text lines. Testing was limited to references published in 2020 and 2021 during the COVID-19 pandemic to avoid retrieving irrelevant references from previous pandemics. For example, no relevant references were published before December 2019 with the free text "severe acute respiratory syndrome".

The results unique to each line were isolated by comparing strategies that did and did not contain the free-text line. For instance, to test Lines 1 and 5:

Line 1: (or/1-23) NOT (or/2-23)

Line 5: (or/1-23) NOT (or/1-4,6-23)

Additional testing was carried out to establish whether the references were uniquely retrieved by that free-text line when subject headings were added to the strategy. For example:

Line 1: (or/1-23) NOT (or/2-23) NOT Subject Headings

Line 5: (or/1-23) NOT (or/1-4,6-23) NOT Subject Headings

The strategies were repeated with limits applied to remove animal studies, non-English language papers and certain publication formats (letters, historical articles, comments, editorials, and news items). The search was also limited to references published in 2020-2021. The applied limits replicated the NICE rapid guideline development process more realistically (NICE, 2020b, section 8). The search was therefore done in the following format:

Line 1: (or/1-23 AND Limits) NOT (or/2-23 AND Limits)

Line 5: (or/1-23 AND Limits) NOT (or/1-4,6-23 AND Limits) 
medRxiv preprint doi: https://doi.org/10.1101/2021.06.11.21258749; this version posted June 14, 2021. The copyright holder for this preprint (which was not certified by peer review) is the author/funder, who has granted medRxiv a license to display the preprint in perpetuity.

It is made available under a CC-BY 4.0 International license .

A RIS file was downloaded from each free-text line containing unique references. The relevancy of these references was assessed by checking the decisions made in the weekly NICE Surveillance process. This process uses the baseline strategy, so NICE had already assessed each reference for relevance. NICE uses EPPI Reviewer version 5 (EPPI-R5) for reference and review management. The Surveillance results were obtained from the relevant EPPI-R5 file on 8 December 2020 to ensure that all the references for this test had been screened. 'Relevant' in this context means that the references were potentially of interest to NICE at title and abstract screening, it does not necessarily mean they would be included in a rapid guideline.

\section{Categorising the free-text lines into five options}

The free-text lines were categorised according to the number of references they retrieved and the number of these relevant to NICE. Each line of free text was categorised as either of 'Critical', 'High', 'Medium', 'Low' or 'Zero' importance to NICE. The categories are explained in Figure 1.

Once the free text had been categorised, five versions of the strategy were developed for further testing (Figure 2). All five versions contained the same subject headings, as the purpose was to test the value of the free text. Strategy A was the baseline and represented the current process. Strategies B-E are progressively more specific. The structure of the strategies is described in Figure 2 and the full searches are available in Appendix D.

Figure 1. Categorising the free-text lines

\begin{tabular}{|l|l|}
\hline \multicolumn{1}{|c|}{ Priority } & \multicolumn{1}{c|}{ Definition } \\
\hline Critical & $\begin{array}{l}\text { Removing this line would mean }>10 \text { relevant references would have } \\
\text { been missed. }\end{array}$ \\
\hline High & $\begin{array}{l}\text { Removing this line would mean 1-10 relevant references would have } \\
\text { been missed. }\end{array}$ \\
\hline Medium & $\begin{array}{l}\text { Removing this line would not affect the number of relevant references } \\
\text { but it has }>1400 \text { results so that suggests the terms are being used in } \\
\text { the literature and could be useful in a sensitive search. }\end{array}$ \\
\hline Low & $\begin{array}{l}\text { Removing this line would not affect the number of relevant references } \\
\text { but it has }<750 \text { results so that suggests the terms not often used. }\end{array}$ \\
\hline Zero & $\begin{array}{l}\text { These lines have zero results and so the terms have never been used in } \\
\text { the COVID-19 literature. }\end{array}$ \\
\hline
\end{tabular}


medRxiv preprint doi: https://doi.org/10.1101/2021.06.11.21258749; this version posted June 14, 2021. The copyright holder for this preprint (which was not certified by peer review) is the author/funder, who has granted medRxiv a license to display the preprint in perpetuity.

It is made available under a CC-BY 4.0 International license .

Figure 2. The five options derived from the categories in Figure 1

\begin{tabular}{|l|l|l|}
\hline $\begin{array}{c}\text { Strategy } \\
\text { option }\end{array}$ & \multicolumn{1}{|c|}{ Free-text lines to retain } & \multicolumn{1}{|c|}{ Free-text lines to remove } \\
\hline A & All lines & None \\
\hline B & Critical, High, Medium, Low & Zero \\
\hline C & Critical, High, Medium & Zero, Low \\
\hline D & Critical, High & Zero, Low, Medium \\
\hline E & Critical & Zero, Low, Medium, High \\
\hline
\end{tabular}

\section{Performance of the five options when searching for drug treatments}

It was not possible to review the relevance of all results retrieved, as each option had over 100,000 results in December 2020. For a feasible number of references to be analysed, the strategies were combined with an intervention concept. The intervention concept contained drugs of potential therapeutic benefit in COVID-19, as this was an area of interest to NICE (NICE, 2020e). A list of drugs was obtained by checking the NICE (https://www.nice.org.uk/covid-19/rapid-c19), European Medicines Agency (EMA) (https://www.ema.europa.eu/en/human-regulatory/overview/publichealth-threats/coronavirus-disease-covid-19/covid-19-whats-new) and US Food and Drug Administration (FDA) (https://www.fda.gov/emergencypreparedness-and-response/mcm-legal-regulatory-and-policyframework/emergency-use-authorization\#coviddrugs) websites on 15 February 2021. A list of 17 drugs was collated, as shown in Figure 3.

Search strategies for the drugs were obtained from previous NICE work. The search strategies for each drug were checked for consistency (e.g. fields used and truncation) and they were made as sensitive as possible (e.g. clinical trial ID numbers were included). The purpose was to test the free text in the five COVID-19 options and so the same drug terms were used in each test.

Test strategies were run in the Ovid segments updated on 15 February 2021, using Strategy $A$ as the baseline. The strategies were in the format:

(COVID-19 Strategy A AND Drug Terms) NOT (COVID-19 Strategy B AND Drug Terms)

The strategies were also run with limits applied for English language, publication date, animal studies and certain publication formats. 
medRxiv preprint doi: https://doi.org/10.1101/2021.06.11.21258749; this version posted June 14, 2021. The copyright holder for this preprint (which was not certified by peer review) is the author/funder, who has granted medRxiv a license to display the preprint in perpetuity.

It is made available under a CC-BY 4.0 International license .

To determine whether any of these results were relevant to NICE, the references that would be missed were screened. 'Relevant' meant a reference that could reasonably be expected in the search results, not one that would necessarily be included after full-text appraisal. The screening was done in EPPI-R5 by the two authors. All references were double screened, and any discrepancies were discussed and reconciled. This screening was done according to the criteria in Figure 3, which were derived from the appropriate NICE methods manual (NICE, 2020e).

Figure 3. Screening criteria for assessing whether references missed by the five search options would be relevant to NICE

\begin{tabular}{|c|c|}
\hline Element & Inclusion criteria \\
\hline Population & $\begin{array}{l}\text { COVID-19 or SARS-COV-2 (including Long COVID or Post-COVID-19 } \\
\text { Syndrome) } \\
\text { Excluding Middle East Respiratory Syndrome Coronavirus or Severe } \\
\text { Acute Respiratory Syndrome } 1\end{array}$ \\
\hline Intervention & $\begin{array}{l}\text { Drug interventions under consideration by NICE, EMA or FDA on } 15 \\
\text { February 2021: } \\
\text { Anakinra } \\
\text { Aspirin } \\
\text { Bamlanivimab } \\
\text { Casirivimab } \\
\text { Celecoxib } \\
\text { Convalescent plasma } \\
\text { Dexamethasone } \\
\text { Hydrocortisone } \\
\text { Hydroxychloroquine } \\
\text { Ibuprofen } \\
\text { Indomethacin } \\
\text { Naproxen } \\
\text { Nimesulide } \\
\text { Remdesivir } \\
\text { Sarilumab } \\
\text { Tocilizumab } \\
\text { Vitamin D }\end{array}$ \\
\hline Comparator & 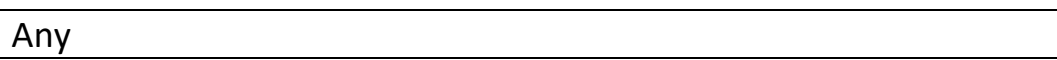 \\
\hline Outcomes & Prevention or treatment of COVID-19 or SARS-COV-2 \\
\hline Study types & $\begin{array}{l}\text { Any - highlight any systematic reviews, clinical trials, observational } \\
\text { studies; and note non-English language, animal studies, letters, or } \\
\text { editorials. }\end{array}$ \\
\hline
\end{tabular}

\section{Comparison with the Ovid COVID-19 Limit}

The testing undertaken up to this point eliminated three of the options but it was insufficient to discriminate between all five of them. Further testing was required to analyse the benefits of Strategies $C$ and $D$. They were compared 
medRxiv preprint doi: https://doi.org/10.1101/2021.06.11.21258749; this version posted June 14, 2021. The copyright holder for this preprint (which was not certified by peer review) is the author/funder, who has granted medRxiv a license to display the preprint in perpetuity.

It is made available under a CC-BY 4.0 International license .

to the COVID-19 Limit that is built into Ovid Embase (Wolters Kluwer, 2021a) and MEDLINE (Wolters Kluwer, 2021b). This comparison was chosen as the search strategies in Lazarus et al. (2020) were designed for PubMed and it was not known how they would perform in Ovid. It was felt to be a realistic comparison, as the Limit was designed using Ovid. The first comparison was made in this format:

Ovid COVID-19 Limit NOT Strategy C

followed by:

\section{Strategy C NOT Ovid COVID-19 Limit}

The results from each search were downloaded as a RIS file and imported into EPPI-R5 for screening. The authors double screened all the results, before discussing and reconciling any discrepancies.

\section{Refinements to create the recommended strategy}

The Ovid COVID-19 Limit comparisons were used to make a final decision on which of the five options to pursue. The chosen strategy was refined further to ensure it was effective. A number of refinements were checked individually, as described in the results section. The refinements had the potential to reduce or increase the overall number of references retrieved. The references that would be added or missed by the refinements were double screened by the authors and any discrepancies were discussed and reconciled. The refinements included checking how best to incorporate subject headings. The final action reduced the number of lines to make it easier to run, without affecting the performance of the strategy.

\section{Results}

\section{Volume from each free-text line}

The number of references retrieved by each line of free text ranged from 0 70,497 in MEDLINE (Table 1) and 0-69,314 in Embase (Table 2). Once the usual NICE limits were applied, retrieval ranged from 0-52,037 and 0-48,442 in MEDLINE and Embase respectively. 
medRxiv preprint doi: https://doi.org/10.1101/2021.06.11.21258749; this version posted June 14, 2021. The copyright holder for this preprint (which was not certified by peer review) is the author/funder, who has granted medRxiv a license to display the preprint in perpetuity.

It is made available under a CC-BY 4.0 International license .

Table 1 shows that nine of the 23 lines retrieved no unique references in MEDLINE, while 14 lines had at least one reference that was not found by any other free text. In MEDLINE, these 14 lines made a unique contribution, even when the strategy incorporated MeSH headings (Table 1).

The numbers differed in Embase (Table 2), although the overall performance was similar: 14 lines found unique references and nine lines found zero. In Embase, 13 free-text lines still made a unique contribution after subject headings were added (Table 2). The Emtree headings now retrieved the reference previously identified by the free text for "HCoV-19".

The highest number of unique references was associated with the line for "COVID-19", which retrieved 12,540 MEDLINE and 1051 Embase references (with limits and subject headings applied) that would have been entirely missed without this free-text line (Tables 1 and 2). 
Table 1. MEDLINE. Search volumes associated with each free-text line (2 December 2020)

\begin{tabular}{|c|c|c|c|c|c|c|}
\hline \multirow[b]{2}{*}{ Free text being tested } & \multicolumn{3}{|c|}{ Full search strategy } & \multicolumn{3}{|c|}{ Limits applied } \\
\hline & $\begin{array}{c}\text { No. of } \\
\text { references } \\
\text { retrieved }\end{array}$ & $\begin{array}{c}\text { No. of } \\
\text { references } \\
\text { unique to this } \\
\text { line when only } \\
\text { free text is } \\
\text { used }\end{array}$ & $\begin{array}{c}\text { No. of } \\
\text { references } \\
\text { unique to this } \\
\text { line when free } \\
\text { text and MeSH } \\
\text { are used }\end{array}$ & $\begin{array}{l}\text { No. of } \\
\text { references } \\
\text { retrieved }\end{array}$ & $\begin{array}{l}\text { No. of } \\
\text { references } \\
\text { unique to this } \\
\text { line when only } \\
\text { free text is } \\
\text { used }\end{array}$ & $\begin{array}{c}\text { No. of } \\
\text { references } \\
\text { unique to this } \\
\text { line when free } \\
\text { text and MeSH } \\
\text { are used }\end{array}$ \\
\hline (corona* adj1 (virus* or viral*)).ti,ab,kw,kf & 2402 & 70 & 65 & 1922 & 47 & 47 \\
\hline (corona* adj1 virinae*).ti,ab,kw,kf & 0 & 0 & 0 & 0 & 0 & 0 \\
\hline (corono* adj1 (virus* or viral*)).ti,ab,kw,kf & 2 & 0 & 0 & 2 & 0 & 0 \\
\hline (corono* adj1 virinae*).ti,ab,kw,kf & 0 & 0 & 0 & 0 & 0 & 0 \\
\hline coronavirus*.ti,ab,kw, kf & 43267 & 2886 & 1423 & 34118 & 1612 & 1059 \\
\hline coronovirus*.ti,ab,kw,kf & 37 & 2 & 2 & 30 & 1 & 1 \\
\hline coronavirinae*.ti,ab,kw,kf & 23 & 0 & 0 & 15 & 0 & 0 \\
\hline coronovirinae* $. \mathrm{ti}, \mathrm{ab}, \mathrm{kw}, \mathrm{kf}$ & 0 & 0 & 0 & 0 & 0 & 0 \\
\hline CoV.ti,ab,kw,kf & 30044 & 191 & 167 & 25113 & 180 & 163 \\
\hline $\begin{array}{l}\text { ("2019-nCoV*" or 2019nCoV* or "19- } \\
\text { nCoV*" or 19nCoV* or nCoV2019* or } \\
\text { "nCoV-2019*" or nCoV19* or "nCoV- } \\
19 * ") . t i, a b, k w, k f\end{array}$ & 1411 & 0 & 0 & 1091 & 0 & 0 \\
\hline $\begin{array}{l}\text { ("COVID-19*" or COVID19* or "COVID- } \\
2019 * " \text { or covid).ti,ab,kw,kf }\end{array}$ & 70497 & 34914 & 17629 & 52037 & 20618 & 12540 \\
\hline $\begin{array}{l}\text { ("HCoV-19*" or HCoV19* or "HCoV-2019*" } \\
\text { or HCoV2019*).ti,ab,kw, kf }\end{array}$ & 21 & 1 & 1 & 19 & 0 & 0 \\
\hline $\begin{array}{l}\text { ("2019 novel*" or Ncov* or "n- } \\
\text { cov").ti,ab,kw,kf }\end{array}$ & 2377 & 6 & 6 & 1888 & 4 & 4 \\
\hline
\end{tabular}




\begin{tabular}{|c|c|c|c|c|c|c|}
\hline $\begin{array}{l}\text { ("SARS-CoV-2*" or "SARSCoV-2*" or } \\
\text { "SARSCoV2*" or "SARS-CoV2*").ti,ab,kw,kf }\end{array}$ & 25185 & 90 & 82 & 21230 & 36 & 35 \\
\hline $\begin{array}{l}\text { (SARSCov19* or "SARS-Cov19*" or } \\
\text { "SARSCov-19*" or "SARS-Cov-19*" or } \\
\text { SARSCov2019* or "SARS-Cov2019*" or } \\
\text { "SARSCov-2019*" or "SARS-Cov- } \\
2019 * ") . t i, a b, k w, k f\end{array}$ & 45 & 0 & 0 & 41 & 0 & 0 \\
\hline (SARS2* or "SARS-2*").ti,ab,kw,kf & 131 & 1 & 1 & 100 & 0 & 0 \\
\hline $\begin{array}{l}\text { (SARScoronavirus2* or "SARS-coronavirus- } \\
\left.2^{* *}\right) . \mathrm{ti}, \mathrm{ab}, \mathrm{kw}, \mathrm{kf}\end{array}$ & 177 & 0 & 0 & 157 & 0 & 0 \\
\hline $\begin{array}{l}\text { ("SARScoronovirus } 2 * " \text { or "SARS } \\
\text { coronovirus2*").ti,ab,kw,kf }\end{array}$ & 0 & 0 & 0 & 0 & 0 & 0 \\
\hline $\begin{array}{l}\text { (respiratory* adj2 (symptom* or disease* } \\
\text { or illness* or condition*) adj5 (Wuhan* or } \\
\text { Hubei* or China* or Chinese* or } \\
\text { Huanan*)).ti,ab,kw,kf }\end{array}$ & 308 & 29 & 29 & 224 & 24 & 24 \\
\hline $\begin{array}{l}\text { (("seafood market*" or "food market*") } \\
\text { adj10 (Wuhan* or Hubei* or China* or } \\
\text { Chinese* or Huanan*)).ti,ab,kw,kf }\end{array}$ & 88 & 3 & 3 & 78 & 2 & 2 \\
\hline $\begin{array}{l}\text { (pneumonia* adj3 (Wuhan* or Hubei* or } \\
\text { China* or Chinese* or } \\
\text { Huanan*)).ti,ab,kw,kf }\end{array}$ & 546 & 47 & 46 & 461 & 45 & 44 \\
\hline $\begin{array}{l}\text { ((outbreak* or wildlife* or pandemic* or } \\
\text { epidemic*) adj1 (Wuhan* or Hubei* or } \\
\text { China* or Chinese* or } \\
\text { Huanan*)).ti,ab,kw,kf }\end{array}$ & 330 & 28 & 27 & 250 & 26 & 26 \\
\hline $\begin{array}{l}\text { "severe acute respiratory } \\
\text { syndrome*".ti,ab,kw,kf }\end{array}$ & 14161 & 22 & 20 & 12454 & 18 & 17 \\
\hline
\end{tabular}


Table 2. Embase. Search volumes associated with each free-text line (2 December 2020)

\begin{tabular}{|c|c|c|c|c|c|c|}
\hline \multirow[b]{2}{*}{ Free text being tested on Embase } & \multicolumn{3}{|c|}{ Full search strategy } & \multicolumn{3}{|c|}{ Limits applied } \\
\hline & $\begin{array}{l}\text { No. of } \\
\text { references } \\
\text { retrieved }\end{array}$ & $\begin{array}{l}\text { No. of } \\
\text { references } \\
\text { unique to this } \\
\text { line when only } \\
\text { free text is } \\
\text { used }\end{array}$ & $\begin{array}{l}\text { No. of } \\
\text { references } \\
\text { unique to this } \\
\text { line when free } \\
\text { text and } \\
\text { Emtree are } \\
\text { used }\end{array}$ & $\begin{array}{l}\text { No. of } \\
\text { references } \\
\text { retrieved }\end{array}$ & $\begin{array}{l}\text { No. of } \\
\text { references } \\
\text { unique to this } \\
\text { line when only } \\
\text { free text is } \\
\text { used }\end{array}$ & $\begin{array}{c}\text { No. of } \\
\text { references } \\
\text { unique to this } \\
\text { line when free } \\
\text { text and } \\
\text { Emtree are } \\
\text { used }\end{array}$ \\
\hline (corona* adj1 (virus* or viral*)).ti,ab,kw & 1880 & 62 & 2 & 1330 & 25 & 1 \\
\hline (corona* adj1 virinae*).ti,ab,kw & 0 & 0 & 0 & 0 & 0 & 0 \\
\hline (corono* adj1 (virus* or viral*)).ti,ab,kw & 1 & 0 & 0 & 1 & 0 & 0 \\
\hline (corono* adj1 virinae*).ti,ab,kw & 0 & 0 & 0 & 0 & 0 & 0 \\
\hline coronavirus*.ti,ab,kw & 43454 & 2945 & 193 & 31688 & 1405 & 144 \\
\hline coronovirus*.ti,ab,kw & 51 & 2 & 1 & 31 & 1 & 1 \\
\hline coronavirinae*.ti,ab,kw & 22 & 0 & 0 & 11 & 0 & 0 \\
\hline coronovirinae*.ti,ab,kw & 0 & 0 & 0 & 0 & 0 & 0 \\
\hline CoV.ti,ab,kw & 30759 & 223 & 185 & 22442 & 166 & 145 \\
\hline $\begin{array}{l}\text { ("2019-nCoV*" or 2019nCoV* or "19- } \\
\text { nCoV*" or 19nCoV* or nCoV2019* or } \\
\text { "nCoV-2019*" or nCoV19* or "nCoV- } \\
19^{* ") . t i, a b, k w} \\
\end{array}$ & 1416 & 0 & 0 & 1018 & 0 & 0 \\
\hline $\begin{array}{l}\text { ("COVID-19*" or COVID19* or "COVID- } \\
\text { 2019*" or covid).ti,ab,kw }\end{array}$ & 69314 & 34909 & 1391 & 48442 & 19470 & 1051 \\
\hline $\begin{array}{l}\text { ("HCoV-19*" or HCoV19* or "HCoV-2019*" } \\
\text { or HCoV2019*).ti,ab,kw }\end{array}$ & 21 & 1 & 0 & 15 & 0 & 0 \\
\hline $\begin{array}{l}\text { ("2019 novel*" or Ncov* or "n- } \\
\text { cov").ti,ab,kw }\end{array}$ & 2417 & 10 & 7 & 1791 & 4 & 4 \\
\hline
\end{tabular}




\begin{tabular}{|c|c|c|c|c|c|c|}
\hline $\begin{array}{l}\text { ("SARS-CoV-2*" or "SARSCoV-2*" or } \\
\text { "SARSCoV2*" or "SARS-CoV2*").ti, ab,kw }\end{array}$ & 24612 & 110 & 12 & 19191 & 38 & 7 \\
\hline $\begin{array}{l}\text { (SARSCov19* or "SARS-Cov19*" or } \\
\text { "SARSCov-19*" or "SARS-Cov-19*" or } \\
\text { SARSCov2019* or "SARS-Cov2019*" or } \\
\text { "SARSCov-2019*" or "SARS-Cov- } \\
2019 * ") . t i, a b, k w\end{array}$ & 48 & 0 & 0 & 40 & 0 & 0 \\
\hline (SARS2* or "SARS-2*").ti,ab,kw & 148 & 2 & 1 & 100 & 1 & 1 \\
\hline $\begin{array}{l}\text { (SARScoronavirus2* or "SARS-coronavirus- } \\
\left.2^{* *}\right) . \mathrm{ti}, \mathrm{ab}, \mathrm{kw}\end{array}$ & 168 & 0 & 0 & 140 & 0 & 0 \\
\hline $\begin{array}{l}\text { ("SARScoronovirus } 2 * " \text { or "SARS } \\
\text { coronovirus2*").ti,ab,kw }\end{array}$ & 0 & 0 & 0 & 0 & 0 & 0 \\
\hline $\begin{array}{l}\text { (respiratory* adj2 (symptom* or disease* } \\
\text { or illness* or condition*) adj5 (Wuhan* or } \\
\text { Hubei* or China* or Chinese* or } \\
\text { Huanan*)).ti,ab,kw }\end{array}$ & 382 & 26 & 26 & 240 & 15 & 15 \\
\hline $\begin{array}{l}\text { (("seafood market*" or "food market*") } \\
\text { adj10 (Wuhan* or Hubei* or China* or } \\
\text { Chinese* or Huanan*)).ti,ab,kw }\end{array}$ & 102 & 3 & 3 & 85 & 2 & 2 \\
\hline $\begin{array}{l}\text { (pneumonia* adj3 (Wuhan* or Hubei* or } \\
\text { China* or Chinese* or Huanan*)).ti,ab,kw }\end{array}$ & 609 & 47 & 46 & 412 & 38 & 37 \\
\hline $\begin{array}{l}\text { ((outbreak* or wildlife* or pandemic* or } \\
\text { epidemic*) adj1 (Wuhan* or Hubei* or } \\
\text { China* or Chinese* or Huanan*)).ti,ab,kw }\end{array}$ & 152 & 11 & 10 & 107 & 8 & 8 \\
\hline $\begin{array}{l}\text { "severe acute respiratory } \\
\text { syndrome*".ti,ab,kw }\end{array}$ & 14283 & 24 & 11 & 11300 & 19 & 10 \\
\hline
\end{tabular}


medRxiv preprint doi: https://doi.org/10.1101/2021.06.11.21258749; this version posted June 14, 2021. The copyright holder for this preprint (which was not certified by peer review) is the author/funder, who has granted medRxiv a license to display the preprint in perpetuity.

It is made available under a CC-BY 4.0 International license .

\section{Relevant references from each free-text line}

The relevance to NICE of the unique references from each free-text line was assessed using EPPI-R5 on 8 December 2020. NICE had screened 103,100 unique references for Surveillance since 16 March 2020 and 6987 had been marked as potentially relevant (with 96,113 excluded from further action). The 6987 references were added to a new EPPI-R5 review and compared to the unique results from each free-text line.

Table 3 shows that three free-text lines retrieved unique references from MEDLINE that were relevant to NICE, with and without limits and MeSH. NICE would have lost 30 relevant MEDLINE references without the free text for "coronavirus", 578 without "COVID-19" and one without "SARS-CoV-2" with limits and MeSH applied (Table 3).

Similar results were obtained from Embase, with four lines having unique references when free text was used and two lines when limits and Emtree were applied (Table 4). In Embase, NICE would lose two unique relevant references without free text for "coronavirus" and 37 without "COVID-19" (with limits and Emtree applied). The Embase lines for "corona adjacent virus" and "SARS-CoV-2" had unique references when using free text but not when Emtree and limits were added. 
Table 3. MEDLINE. Number of relevant references that would be lost by removing the free-text line (2 December 2020)

\begin{tabular}{|c|c|c|c|c|}
\hline \multirow[b]{2}{*}{ Free text being tested } & \multicolumn{2}{|c|}{ Full search strategy } & \multicolumn{2}{|c|}{ Limits applied } \\
\hline & $\begin{array}{l}\text { No. of relevant } \\
\text { references unique } \\
\text { to this line when } \\
\text { only free text is } \\
\text { used }\end{array}$ & $\begin{array}{l}\text { No. of relevant references } \\
\text { unique to this line when } \\
\text { free text and MeSH are } \\
\text { used }\end{array}$ & $\begin{array}{l}\text { No. of relevant } \\
\text { references unique to } \\
\text { this line when only free } \\
\text { text is used }\end{array}$ & $\begin{array}{l}\text { No. of relevant } \\
\text { references unique to } \\
\text { this line when free text } \\
\text { and MeSH are used }\end{array}$ \\
\hline (corona* adj1 (virus* or viral*)).ti,ab,kw,kf & 0 & 0 & 0 & 0 \\
\hline (corona* adj1 virinae*).ti,ab,kw,kf & 0 & 0 & 0 & 0 \\
\hline (corono* adj1 (virus* or viral*)).ti,ab,kw,kf & 0 & 0 & 0 & 0 \\
\hline (corono* adj1 virinae*).ti,ab,kw,kf & 0 & 0 & 0 & 0 \\
\hline coronavirus*.ti,ab,kw, kf & 90 & 31 & 63 & 30 \\
\hline coronovirus*.ti,ab,kw,kf & 0 & 0 & 0 & 0 \\
\hline coronavirinae*.ti,ab, kw, kf & 0 & 0 & 0 & 0 \\
\hline coronovirinae*.ti,ab,kw,kf & 0 & 0 & 0 & 0 \\
\hline CoV.ti,ab,kw,kf & 0 & 0 & 0 & \\
\hline $\begin{array}{l}\text { ("2019-nCoV*" or 2019nCoV* or "19- } \\
\text { nCoV*" or } 19 n C o n^{*} \text { or nCoV2019* or } \\
\text { "nCoV-2019*" or nCoV19* or "nCoV- } \\
19^{* 1) . t i, a b, k w, k f ~}\end{array}$ & 0 & 0 & 0 & 0 \\
\hline $\begin{array}{l}\text { ("COVID-19*" or COVID19* or "COVID- } \\
2019 * " \text { or covid).ti,ab,kw,kf }\end{array}$ & 1553 & 673 & 1044 & 578 \\
\hline $\begin{array}{l}\text { ("HCoV-19*" or HCoV19* or "HCoV-2019*" } \\
\text { or HCoV2019*).ti,ab,kw,kf }\end{array}$ & 0 & 0 & 0 & 0 \\
\hline $\begin{array}{l}\text { ("2019 novel*" or Ncov* or "n- } \\
\text { cov").ti,ab,kw,kf }\end{array}$ & 0 & 0 & 0 & 0 \\
\hline
\end{tabular}




\begin{tabular}{|c|c|c|c|c|}
\hline $\begin{array}{l}\text { ("SARS-CoV- } 2 * \text { " or "SARSCoV- } 2 * \text { " or } \\
\text { "SARSCoV2*" or "SARS-CoV2*").ti,ab,kw,kf }\end{array}$ & 2 & 2 & 1 & 1 \\
\hline $\begin{array}{l}\text { (SARSCov19* or "SARS-Cov19*" or } \\
\text { "SARSCov-19*" or "SARS-Cov-19*" or } \\
\text { SARSCov2019* or "SARS-Cov2019*" or } \\
\text { "SARSCov-2019*" or "SARS-Cov- } \\
2019 * " \text {.ti,ab,kw,kf }\end{array}$ & 0 & 0 & 0 & 0 \\
\hline (SARS2* or "SARS-2*").ti,ab,kw,kf & 0 & 0 & 0 & 0 \\
\hline $\begin{array}{l}\text { (SARScoronavirus2* or "SARS-coronavirus- } \\
\left.2^{*} "\right) . t \mathrm{t}, \mathrm{ab}, \mathrm{kw}, \mathrm{kf}\end{array}$ & 0 & 0 & 0 & 0 \\
\hline $\begin{array}{l}\text { ("SARScoronovirus } 2 * \text { " or "SARS } \\
\text { coronovirus } 2 * ") . t i, a b, k w, k f\end{array}$ & 0 & 0 & 0 & 0 \\
\hline $\begin{array}{l}\text { (respiratory* adj2 (symptom* or disease* } \\
\text { or illness* or condition*) adj5 (Wuhan* or } \\
\text { Hubei* or China* or Chinese* or } \\
\text { Huanan*)).ti,ab,kw,kf }\end{array}$ & 0 & 0 & 0 & 0 \\
\hline $\begin{array}{l}\text { (("seafood market*" or "food market*") } \\
\text { adj10 (Wuhan* or Hubei* or China* or } \\
\text { Chinese* or Huanan*)).ti,ab,kw,kf }\end{array}$ & 0 & 0 & 0 & 0 \\
\hline $\begin{array}{l}\text { (pneumonia* adj3 (Wuhan* or Hubei* or } \\
\text { China* or Chinese* or } \\
\text { Huanan*)).ti,ab,kw,kf }\end{array}$ & 0 & 0 & 0 & 0 \\
\hline $\begin{array}{l}\text { ((outbreak* or wildlife* or pandemic* or } \\
\text { epidemic*) adj1 (Wuhan* or Hubei* or } \\
\text { China* or Chinese* or } \\
\text { Huanan*)).ti,ab,kw,kf }\end{array}$ & 0 & 0 & 0 & 0 \\
\hline $\begin{array}{l}\text { "severe acute respiratory } \\
\text { syndrome*".ti,ab,kw,kf }\end{array}$ & 0 & 0 & 0 & 0 \\
\hline
\end{tabular}


Table 4. Embase. Number of relevant references that would be lost by removing the free-text line (2 December 2020$)$

\begin{tabular}{|c|c|c|c|c|}
\hline \multirow[b]{2}{*}{ Free text being tested on Embase } & \multicolumn{2}{|c|}{ Full search strategy } & \multicolumn{2}{|c|}{ Limits applied } \\
\hline & $\begin{array}{l}\text { No. of relevant } \\
\text { references unique } \\
\text { to this line when } \\
\text { only free text is } \\
\text { used }\end{array}$ & $\begin{array}{l}\text { No. of relevant references } \\
\text { unique to this line when } \\
\text { free text and Emtree are } \\
\text { used }\end{array}$ & $\begin{array}{l}\text { No. of relevant } \\
\text { references unique to } \\
\text { this line when only free } \\
\text { text is used }\end{array}$ & $\begin{array}{l}\text { No. of relevant } \\
\text { references unique to } \\
\text { this line when free text } \\
\text { and Emtree are used }\end{array}$ \\
\hline (corona* adj1 (virus* or viral*)).ti,ab,kw & 1 & 0 & 1 & 0 \\
\hline (corona* adj1 virinae*).ti,ab,kw & 0 & 0 & 0 & 0 \\
\hline (corono* adj1 (virus* or viral*)).ti,ab,kw & 0 & 0 & 0 & 0 \\
\hline (corono* adj1 virinae*).ti,ab,kw & 0 & 0 & 0 & 0 \\
\hline coronavirus*.ti,ab,kw & 1128 & 6 & 116 & 2 \\
\hline coronovirus*.ti,ab,kw & 0 & 0 & 0 & 0 \\
\hline coronavirinae*.ti,ab,kw & 0 & 0 & 0 & 0 \\
\hline coronovirinae*.ti,ab,kw & 0 & 0 & 0 & 0 \\
\hline CoV.ti,ab,kw & 0 & 0 & 0 & 0 \\
\hline $\begin{array}{l}\text { ("2019-nCoV*" or 2019nCoV* or "19- } \\
\text { nCoV*" or } 19 n \mathrm{CoV}^{*} \text { or nCoV2019* or } \\
\text { "nCoV-2019*" or nCoV19* or "nCoV- } \\
19^{* 1) . t i, a b, k w}\end{array}$ & 0 & 0 & 0 & 0 \\
\hline $\begin{array}{l}\text { ("COVID-19*" or COVID19* or "COVID- } \\
2019 * " \text { or covid).ti,ab,kw }\end{array}$ & 4096 & 48 & 1779 & 37 \\
\hline $\begin{array}{l}\text { ("HCoV-19*" or HCoV19* or "HCoV-2019*" } \\
\text { or HCoV2019*).ti,ab,kw }\end{array}$ & 0 & 0 & 0 & 0 \\
\hline $\begin{array}{l}\text { ("2019 novel*" or Ncov* or "n- } \\
\text { cov").ti,ab,kw }\end{array}$ & 0 & 0 & 0 & 0 \\
\hline
\end{tabular}




\begin{tabular}{|c|c|c|c|c|}
\hline $\begin{array}{l}\text { ("SARS-CoV-2*" or "SARSCoV-2*" or } \\
\text { "SARSCoV2*" or "SARS-CoV2*").ti,ab,kw }\end{array}$ & 3 & 0 & 1 & 0 \\
\hline $\begin{array}{l}\text { (SARSCov19* or "SARS-Cov19*" or } \\
\text { "SARSCov-19*" or "SARS-Cov-19*" or } \\
\text { SARSCov2019* or "SARS-Cov2019*" or } \\
\text { "SARSCov-2019*" or "SARS-Cov- } \\
2019 * ") . t i, a b, k w\end{array}$ & 0 & 0 & 0 & 0 \\
\hline (SARS2* or "SARS-2*").ti,ab,kw & 0 & 0 & 0 & 0 \\
\hline $\begin{array}{l}\text { (SARScoronavirus2* or "SARS-coronavirus- } \\
2^{* *) . t i, a b, k w}\end{array}$ & 0 & 0 & 0 & 0 \\
\hline $\begin{array}{l}\text { ("SARScoronovirus } 2 * " \text { or "SARS } \\
\text { coronovirus2*").ti,ab,kw }\end{array}$ & 0 & 0 & 0 & 0 \\
\hline $\begin{array}{l}\text { (respiratory* adj2 (symptom* or disease* } \\
\text { or illness* or condition*) adj5 (Wuhan* or } \\
\text { Hubei* or China* or Chinese* or } \\
\text { Huanan*)).ti,ab,kw }\end{array}$ & 0 & 0 & 0 & 0 \\
\hline $\begin{array}{l}\text { (("seafood market*" or "food market*") } \\
\text { adj10 (Wuhan* or Hubei* or China* or } \\
\text { Chinese* or Huanan*)).ti,ab,kw }\end{array}$ & 0 & 0 & 0 & 0 \\
\hline $\begin{array}{l}\text { (pneumonia* adj3 (Wuhan* or Hubei* or } \\
\text { China* or Chinese* or Huanan*)).ti,ab,kw }\end{array}$ & 0 & 0 & 0 & 0 \\
\hline $\begin{array}{l}\text { ((outbreak* or wildlife* or pandemic* or } \\
\text { epidemic*) adj1 (Wuhan* or Hubei* or } \\
\text { China* or Chinese* or Huanan*)).ti,ab,kw }\end{array}$ & 0 & 0 & 0 & 0 \\
\hline $\begin{array}{l}\text { "severe acute respiratory } \\
\text { syndrome*".ti,ab,kw }\end{array}$ & 0 & 0 & 0 & 0 \\
\hline
\end{tabular}


medRxiv preprint doi: https://doi.org/10.1101/2021.06.11.21258749; this version posted June 14, 2021. The copyright holder for this preprint (which was not certified by peer review) is the author/funder, who has granted medRxiv a license to display the preprint in perpetuity.

It is made available under a CC-BY 4.0 International license .

\section{Categorising the free-text lines into five options}

The results in Tables 1-4 were used to categorise the free-text lines according to the criteria in Figure 1 and to create the five options in Figure 2, which are detailed in Appendix $\mathrm{D}$. The same decisions on the free-text lines were made in both databases, although there were some minor discrepancies between the MEDLINE and Embase results (outlined in Tables 1-4). Relevant free-text terms in one database are likely to contribute in the other.

As indicated in Tables 1-2, four lines did not retrieve a single reference and were unlikely to contribute relevant references to NICE. These lines were categorised as 'Zero' and removed to create Strategy B. Several lines were categorised as 'Low' priority, including the line for pneumonia adjacent to Wuhan. This line did retrieve 44 unique references in MEDLINE (Table 1) and 37 in Embase (Table 2), when limits and subject headings were applied, although none were relevant to NICE (Tables 3-4). The terms were occasionally used in the literature but there was a low chance of the results being relevant to NICE.

Four lines, categorised as 'Medium', did not retrieve any unique references relevant to NICE but were retained in Strategy $C$ because the free-text terms were often used in the literature. For example, the term "CoV" retrieved 30,044 references from MEDLINE (Table 1) and 30,759 from Embase (Table 2 ) without limits or subject headings applied, although none of the references unique to this line were relevant to NICE (Tables 3-4).

Two lines were categorised as 'High' and were included in Strategy D. The line featuring "corona adjacent to virus or viral" had no unique relevant references from MEDLINE (Table 3) and one from Embase (Table 4). The free-text terms for "SARS-CoV-2" had high recall $(25,185$ MEDLINE results in Table 1 and 24,612 from Embase in Table 2), but only two unique references from MEDLINE (Table 3) and three from Embase (Table 4) were relevant.

Two lines, categorised as 'Critical', were added to Strategy E. The term "coronavirus" retrieved 90 unique relevant references in MEDLINE (Table 3) and 1128 in Embase (Table 4) that would have been missed without this free 
medRxiv preprint doi: https://doi.org/10.1101/2021.06.11.21258749; this version posted June 14, 2021. The copyright holder for this preprint (which was not certified by peer review) is the author/funder, who has granted medRxiv a license to display the preprint in perpetuity.

It is made available under a CC-BY 4.0 International license .

text. "COVID-19" retrieved 1553 unique relevant references in MEDLINE (Table 3) and 4096 in Embase (Table 4) without subject headings or limits.

\section{Performance of the five options when searching for drugs}

The five options were tested with sensitive searches for the 17 drugs listed in Figure 3 using the Ovid segments dated 15 February 2021. The references that would be missed by the more specific options were downloaded, as RIS files, and imported into EPPI-R5. Table 5 shows there were six MEDLINE results to review from Strategy $C, 22$ from $D$ and 105 from $E$; and in Embase there were 15 from Strategy C, 78 from $D$ and 86 from $E$. The references were screened independently and there was $88 \%$ agreement before reconciling the discrepancies.

Table 5 shows that the number of MEDLINE results for the drug treatments ranged from 5389-5494 with the full search and 4231-4281 after applying limits. In Embase, the results, with limits applied, ranged from 7175-7196. The screening process found that no relevant references would be lost, from MEDLINE or Embase, if Strategies B or C were used instead of Strategy A.

Table 5 shows that Strategy B consistently retrieved the same number of results as the baseline. Strategy $A$ was excluded from further testing as these additional free-text lines were not required.

Strategy E missed 72 relevant references from MEDLINE, including 33 when limits were applied. Strategy $E$ missed a total of seven relevant references in Embase, of which four would be missed when limits were applied (Table 5). As there was a high risk of missing relevant references from this increase in specificity, Strategy $\mathrm{E}$ was eliminated from further testing.

Strategy C and Strategy D were retained for further testing. Compared to Strategy A, Strategy $C$ was shorter and retrieved six fewer references in MEDLINE and 15 in Embase, none of which were relevant (Table 5). Strategy $D$ missed one relevant reference in both databases with limits applied (Seghatchian, 2021). It did not seem necessary to eliminate Strategy $D$ at this stage, as there was potential to refine it further. 
Table 5. MEDLINE and Embase. Performance of the five options when searching for drug treatments (15 February 2021)

\begin{tabular}{|c|c|c|c|c|c|}
\hline \multirow{2}{*}{$\begin{array}{l}\text { Search } \\
\text { strategy }\end{array}$} & \multirow[b]{2}{*}{ Element } & \multicolumn{2}{|c|}{ MEDLINE } & \multicolumn{2}{|c|}{ Embase } \\
\hline & & $\begin{array}{c}\text { Full } \\
\text { search }\end{array}$ & $\begin{array}{l}\text { Limits } \\
\text { applied }\end{array}$ & $\begin{array}{c}\text { Full } \\
\text { search }\end{array}$ & $\begin{array}{l}\text { Limits } \\
\text { applied }\end{array}$ \\
\hline \multirow{2}{*}{ A Zero } & COVID-19 terms & 126978 & 78535 & 130786 & 69763 \\
\hline & COVID-19 AND Drugs & 5494 & 4281 & 10464 & 7196 \\
\hline \multirow{4}{*}{ B Low } & COVID-19 terms & 126978 & 78535 & 130786 & 69763 \\
\hline & COVID-19 AND Drugs & 5494 & 4281 & 10464 & 7196 \\
\hline & $\begin{array}{l}\text { No. lower than the } \\
\text { baseline }\end{array}$ & 0 & 0 & 0 & 0 \\
\hline & $\begin{array}{l}\text { No. of missed references } \\
\text { that are relevant }\end{array}$ & $x$ & $x$ & $x$ & $x$ \\
\hline \multirow{4}{*}{ C Medium } & COVID-19 terms & 126180 & 78422 & 129992 & 69692 \\
\hline & COVID-19 AND Drugs & 5488 & 4281 & 10449 & 7195 \\
\hline & $\begin{array}{l}\text { No. lower than the } \\
\text { baseline }\end{array}$ & 6 & 0 & 15 & 1 \\
\hline & $\begin{array}{l}\text { No. of missed references } \\
\text { that are relevant }\end{array}$ & 0 & $x$ & 0 & 0 \\
\hline \multirow{4}{*}{ D High } & COVID-19 terms & 124131 & 78183 & 127374 & 67269 \\
\hline & COVID-19 AND Drugs & 5472 & 4279 & 10386 & 7182 \\
\hline & $\begin{array}{l}\text { No. lower than the } \\
\text { baseline }\end{array}$ & 22 & 2 & 78 & 14 \\
\hline & $\begin{array}{l}\text { No. of missed references } \\
\text { that are relevant }\end{array}$ & 2 & 1 & 2 & 1 \\
\hline \multirow{4}{*}{ E Critical } & COVID-19 terms & 121491 & 76583 & 126881 & 67012 \\
\hline & COVID-19 AND Drugs & 5389 & 4231 & 10378 & 7175 \\
\hline & $\begin{array}{l}\text { No. lower than the } \\
\text { baseline }\end{array}$ & 105 & 50 & 86 & 21 \\
\hline & $\begin{array}{l}\text { No. of missed references } \\
\text { that are relevant }\end{array}$ & 72 & 33 & 7 & 4 \\
\hline
\end{tabular}

\section{Comparison with the Ovid COVID-19 Limit}

The recall of Strategies C and D was tested against the Ovid COVID-19 Limits. Strategy $C$ had 78,422 MEDLINE results with limits applied and missed 308 of the 78,221 references in the Ovid Limit (Table 6). After screening, 11 of the 308 were found to be relevant to NICE. Strategy D had 78,183 MEDLINE results and missed 332 from the Ovid Limit, of which 31 were relevant (Table 6). 
Table 6. MEDLINE. Comparison of the Ovid COVID-19 Limit to Strategies C and D (15 February 2021)

\begin{tabular}{|l|r|r|r|r|}
\hline \multicolumn{1}{|c|}{ Strategy } & \multicolumn{1}{|c|}{$\begin{array}{c}\text { Total } \\
\text { references } \\
\text { retrieved }\end{array}$} & $\begin{array}{c}\text { Total } \\
\text { references } \\
\text { retrieved with } \\
\text { limits applied }\end{array}$ & $\begin{array}{c}\text { References } \\
\text { retrieved by } \\
\text { Ovid and } \\
\text { missed by NICE }\end{array}$ & $\begin{array}{c}\text { No. of missed } \\
\text { references } \\
\text { relevant to } \\
\text { NICE }\end{array}$ \\
\hline $\begin{array}{l}\text { Ovid COVID-19 } \\
\text { Limit }\end{array}$ & 107058 & 78221 & $\mathrm{x}$ & $\mathrm{x}$ \\
\hline Strategy C & 126180 & 78422 & 308 & 11 \\
\hline Strategy D & 124131 & 78183 & 332 & 31 \\
\hline
\end{tabular}

Similarly, in Embase, Strategy C missed 65 references retrieved by the Ovid COVID-19 Limit and 24 of these were relevant to NICE, while Strategy D missed 74 and 31 were relevant (Table 7).

Table 7. Embase. Comparison of the Ovid COVID-19 Limit to Strategies C and D (6 April 2021)

\begin{tabular}{|l|r|r|r|r|}
\hline \multicolumn{1}{|c|}{$\begin{array}{c}\text { Embase } \\
\text { Strategy }\end{array}$} & $\begin{array}{c}\text { Total } \\
\text { references } \\
\text { retrieved }\end{array}$ & $\begin{array}{c}\text { Total } \\
\text { references } \\
\text { retrieved with } \\
\text { limits applied }\end{array}$ & $\begin{array}{c}\text { References } \\
\text { retrieved by } \\
\text { Ovid and } \\
\text { missed by NICE }\end{array}$ & $\begin{array}{c}\text { No. of missed } \\
\text { references } \\
\text { relevant to } \\
\text { NICE }\end{array}$ \\
\hline $\begin{array}{l}\text { Ovid COVID-19 } \\
\text { Limit }\end{array}$ & 126059 & 83446 & $\times$ & $\times$ \\
\hline Strategy C & 150928 & 84139 & 65 & 24 \\
\hline Strategy D & 148279 & 83924 & 74 & 31 \\
\hline
\end{tabular}

Strategy D missed 20 more relevant references than Strategy C in MEDLINE (Table 6) and seven more in Embase (Table 7). Strategy $C$ was therefore prioritised for the next test, as it achieved appropriate specificity for NICE. The difference between Strategy $C$ and $D$ is the inclusion of free text (categorised as 'Medium'), covering "CoV", "2019-nCoV", "2019 novel" and "severe acute respiratory syndrome".

Tests were run to investigate the references retrieved by Strategy $C$ and missed by the Ovid COVID-19 Limit. The Ovid Limit in MEDLINE missed 514 references found by Strategy C (Table 8). Strategy C correctly identified 280 references (for example, they referred to coronaviruses in the abstract) and the rest were correctly excluded by Ovid (for example, "CoV" was an abbreviation for "Coefficients of Variation"). The $\mathbf{2 8 0}$ were screened again and 256 were excluded on relevance (for instance, references to Feline Coronavirus or Coronavirus NL63) and 24 were identified as relevant to COVID-19 for NICE. This process was repeated in Embase, which found that 
medRxiv preprint doi: https://doi.org/10.1101/2021.06.11.21258749; this version posted June 14, 2021. The copyright holder for this preprint (which was not certified by peer review) is the author/funder, who has granted medRxiv a license to display the preprint in perpetuity.

It is made available under a CC-BY 4.0 International license .

the Ovid Limit missed 758 references retrieved by Strategy C, 12 of which were relevant to NICE (Table 9).

Table 8. MEDLINE. Comparison of Strategy C to the Ovid COVID-19 Limit (5 March 2021)

\begin{tabular}{|l|r|r|r|r|r|}
\hline \multicolumn{1}{|c|}{ Strategy } & $\begin{array}{c}\text { Total } \\
\text { references } \\
\text { retrieved }\end{array}$ & $\begin{array}{c}\text { Total } \\
\text { references } \\
\text { retrieved } \\
\text { with limits } \\
\text { applied }\end{array}$ & $\begin{array}{c}\text { References } \\
\text { retrieved by } \\
\text { NICE and } \\
\text { missed by } \\
\text { Ovid }\end{array}$ & $\begin{array}{c}\text { No. of missed } \\
\text { references } \\
\text { correctly } \\
\text { retrieved }\end{array}$ & $\begin{array}{c}\text { No. of missed } \\
\text { references } \\
\text { relevant to } \\
\text { NICE }\end{array}$ \\
\hline $\begin{array}{l}\text { Ovid COVID- } \\
19 \text { Limit }\end{array}$ & 112836 & 82716 & 514 & 280 & 24 \\
\hline Strategy C & 132621 & 83123 & $\mathrm{x}$ & $\mathrm{x}$ & $\mathrm{x}$ \\
\hline
\end{tabular}

Table 9. Embase. Comparison of Strategy C to the Ovid COVID-19 Limit (6 April 2021)

\begin{tabular}{|l|r|r|r|r|r|}
\hline \multicolumn{1}{|c|}{ Embase } & \multicolumn{1}{|c|}{$\begin{array}{c}\text { Total } \\
\text { refrategy } \\
\text { retriences }\end{array}$} & $\begin{array}{c}\text { Total } \\
\text { references } \\
\text { retrieved } \\
\text { with limits } \\
\text { applied }\end{array}$ & $\begin{array}{c}\text { References } \\
\text { retrieved by } \\
\text { NICE and } \\
\text { missed by } \\
\text { Ovid }\end{array}$ & $\begin{array}{c}\text { No. of missed } \\
\text { references } \\
\text { correctly } \\
\text { retrieved }\end{array}$ & $\begin{array}{c}\text { No. of missed } \\
\text { references } \\
\text { relevant to } \\
\text { NICE }\end{array}$ \\
\hline $\begin{array}{l}\text { Ovid COVID- } \\
\text { 19 Limit }\end{array}$ & 126059 & 83446 & 758 & 646 & 12 \\
\hline Strategy C & 150928 & 84139 & $\mathrm{x}$ & $\mathrm{x}$ & $\mathrm{x}$ \\
\hline
\end{tabular}

\section{Refinements to create the recommended strategy}

The screening for Tables 6-9 highlighted several potential refinements that could be made to Strategy $C$. The full test strategies are available in the supplementary information (File A for MEDLINE and File B for Embase).

One of the issues identified in Tables 6-7 was that the Ovid COVID-19 Limit retrieved references that mentioned "pandemic" without specifying COVID-19. For this reason, adding the free-text term "pandemic" was considered too broad. However, the free-text term "corona pandemic" was tested and rejected (Tables 10-11). Testing also showed that there was little value in using a wildcard to retrieve the misspelling "coronvirus".

The screening for Tables 8-9 highlighted the imprecision of the term "CoV", as it was used to abbreviate phrases such as "cut-off volume" and "central vessel trunk" as well as COVID-19. These terms could be excluded from the strategy using a Boolean NOT operator, as none of the 159 references in MEDLINE (Table 10) nor the 162 references in Embase (Table 11) discussed COVID- 
medRxiv preprint doi: https://doi.org/10.1101/2021.06.11.21258749; this version posted June 14, 2021. The copyright holder for this preprint (which was not certified by peer review) is the author/funder, who has granted medRxiv a license to display the preprint in perpetuity.

It is made available under a CC-BY 4.0 International license .

19. The decision to exclude these terms was adopted in the final strategy. The exclusions were only applied to this specific free-text line, rather than the whole strategy, to ensure references discussing COVID-19 were not inadvertently excluded.

In Strategy C, terms such as "nCoV2019*" and "nCoV-2019*" had been included. Testing showed that these terms were captured by "Ncov"and could be removed, with no negative impact. Additional techniques were also explored but rejected: removing the truncation from "Ncov" would lose one relevant reference from both MEDLINE and Embase, while truncating the phrase "n-cov" added six MEDLINE and eight Embase references of no relevance to NICE (Tables 10-11).

Changes to the free text for "COVID-19" were tested. As Strategy C included "COVID-2019*", the term "COVID2019*" was checked for consistency. This addition was rejected as it retrieved no references in either database.

The term "covid" had been used without truncation in Strategy C. However, this contributed to relevant references being missed that were retrieved by the Ovid Limit (Tables 6-7). Applying unlimited truncation increased the MEDLINE results by 135, of which seven were relevant to NICE (Table 10). In Embase, only two of the 139 additional results were relevant (Table 11). To retrieve the relevant references, while limiting the number of irrelevant records, a more specific version was tested. By using the Ovid command to limit truncation to two characters, the number of references retrieved by Strategy $C$ increased by four in both MEDLINE and Embase, of which two were relevant (Tables 10-11). Therefore, the term "COVID*2" was added to the strategy, which allowed the free-text line to be simplified, as this captured the individual terms: "COVID-19*", "COVID19*" and "COVID-2019*". Testing confirmed that removing these terms did not affect the results in either database.

Up to this point, the exploded MeSH headings "Coronavirus" and "Coronavirus infections" had been used. It was felt that the specificity of the strategy could be improved once Ovid had incorporated MeSH 2021. Several variations were tested. The first version included MeSH headings from higher 
medRxiv preprint doi: https://doi.org/10.1101/2021.06.11.21258749; this version posted June 14, 2021. The copyright holder for this preprint (which was not certified by peer review) is the author/funder, who has granted medRxiv a license to display the preprint in perpetuity.

It is made available under a CC-BY 4.0 International license .

in the hierarchy ("Coronavirus", "Betacoronavirus" and "Coronavirus Infections") to exclude irrelevant headings (such as "Alphacoronavirus 1") that were previously being retrieved. This reduced Strategy $C$ by two results (Table 10). Next, using only headings from lower in the MeSH hierarchy ("SARS-CoV-2" and "COVID-19") was tested. This reduced Strategy C by 23 results, although four of these mentioned COVID-19, none were relevant to NICE. Additional MeSH 2021 headings were tested ("COVID-19 Testing" and "COVID-19 Vaccines") but none of the five results were relevant to NICE.

The baseline Embase strategy used exploded headings "Coronavirinae" and "Coronavirus infection". It also included the proposed Emtree headings "Coronavirus disease 2019" and "Severe acute respiratory syndrome coronavirus 2" using the subject heading (.sh) and proposed candidate (.dj) fields. The testing was done in April 2021, when the latest version of Emtree had been loaded into Ovid Embase. The test showed that "Coronavirus disease 2019" and "Severe acute respiratory syndrome coronavirus 2" were now full Emtree headings and could be used in that way.

Individual Emtree headings situated higher in the hierarchy ("Coronavirinae", "Betacoronavirus", "SARS-related coronavirus" and "Coronavirus infection") were tested in place of exploding "Coronavirinae" and "Coronavirus infection". This change reduced the results from Strategy $C$ by 90 . The next test found that using only headings from lower in the hierarchy ("Severe acute respiratory syndrome coronavirus 2" or "Coronavirus disease 2019") reduced results by 204 , of which 22 were relevant to COVID-19 and one to NICE. The one relevant reference that NICE would miss (Cournoyer et al., 2021) discussed respiratory viruses in general (e.g. influenza) and had been indexed with the Emtree heading for SARS-CoV-1. The full-text paper was considered to have minimal value to NICE. Therefore, the decision to only use Emtree headings from lower in the hierarchy was retained.

The Emtree heading "Experimental coronavirus disease 2019", had been used to index 11 references at the time of testing. Although none of the results were unique to the heading, it could become important over time. Therefore, the heading was included in Strategy $\mathrm{C}$. 
Table 10. MEDLINE. Refinements to Strategy C (15 March to 12 April 2021)

\begin{tabular}{|c|c|c|c|c|}
\hline Refinement to Strategy C & \begin{tabular}{|c|} 
Effect on the \\
total references \\
retrieved (limits \\
applied)
\end{tabular} & $\begin{array}{l}\text { No. of affected } \\
\text { references } \\
\text { relevant to } \\
\text { COVID-19 }\end{array}$ & $\begin{array}{c}\text { No. relevant } \\
\text { to NICE }\end{array}$ & Decision \\
\hline $\begin{array}{l}\text { Line } 1 \\
\text { Including MeSH headings } \\
\text { from higher in the } \\
\text { hierarchy }\end{array}$ & -2 & 0 & 0 & Reject \\
\hline $\begin{array}{l}\text { Line } 1 \\
\text { Adding new MeSH for } \\
\text { Vaccines and Testing }\end{array}$ & 5 & 5 & 0 & Reject \\
\hline $\begin{array}{l}\text { Line } 1 \\
\text { Making MeSH more } \\
\text { precise - headings lower } \\
\text { in the hierarchy }\end{array}$ & -23 & 4 & 0 & Retain \\
\hline $\begin{array}{l}\text { Line } 3 \\
\text { (corona* adj1 } \\
\text { pandemic*) }\end{array}$ & 12 & 11 & 0 & Reject \\
\hline $\begin{array}{l}\text { Line } 4 \\
\text { coron?virus*.ti,ab,kw,kf. }\end{array}$ & 1 & 1 & 0 & Reject \\
\hline $\begin{array}{l}\text { Line } 5 \\
\text { NOT CoV terms }\end{array}$ & -157 & 0 & 0 & Retain \\
\hline $\begin{array}{l}\text { Line } 5 \\
\text { NOT additional CoV } \\
\text { terms }\end{array}$ & -159 & 0 & 0 & Retain \\
\hline $\begin{array}{l}\text { Line } 6 \\
\text { Remove variants of } \mathrm{nCoV}\end{array}$ & 0 & 0 & 0 & Retain \\
\hline $\begin{array}{l}\text { Line } 7 \\
\text { Add COVID2019 }\end{array}$ & 0 & 0 & 0 & Reject \\
\hline $\begin{array}{l}\text { Line } 7 \\
\text { COVID* }\end{array}$ & 135 & 8 & 7 & Reject \\
\hline $\begin{array}{l}\text { Line } 7 \\
\text { COVID*2 }\end{array}$ & 4 & 3 & 2 & Retain \\
\hline $\begin{array}{l}\text { Line } 7 \\
\text { COVID*2 remove } \\
\text { COVID19 }\end{array}$ & 0 & 0 & 0 & Retain \\
\hline $\begin{array}{l}\text { Line } 8 \\
\text { "n-cov*" }\end{array}$ & 6 & 0 & 0 & Reject \\
\hline $\begin{array}{l}\text { Line } 8 \\
\text { Ncov without truncation }\end{array}$ & -2 & 2 & 1 & Reject \\
\hline
\end{tabular}


Table 11. Embase. Refinements to Strategy C (9 April 2021)

\begin{tabular}{|c|c|c|c|c|}
\hline $\begin{array}{c}\text { Refinement to Embase } \\
\text { Strategy C }\end{array}$ & \begin{tabular}{|c|} 
Effect on the \\
total references \\
retrieved (limits \\
applied)
\end{tabular} & $\begin{array}{l}\text { No. of affected } \\
\text { references } \\
\text { relevant to } \\
\text { COVID-19 }\end{array}$ & $\begin{array}{c}\text { No. relevant } \\
\text { to NICE }\end{array}$ & Decision \\
\hline $\begin{array}{l}\text { Line } 1 \\
\text { Including Emtree } \\
\text { headings from higher in } \\
\text { the hierarchy }\end{array}$ & -90 & 2 & 0 & Reject \\
\hline $\begin{array}{l}\text { Line } 1 \\
\text { Adding new Emtree } \\
\text { heading for experimental } \\
\text { coronavirus }\end{array}$ & 0 & 0 & 0 & Retain \\
\hline $\begin{array}{l}\text { Line } 1 \\
\text { Making Emtree more } \\
\text { precise - headings lower } \\
\text { in the hierarchy }\end{array}$ & -204 & 22 & 1 & Retain \\
\hline $\begin{array}{l}\text { Line } 3 \\
\text { Check that .sh,dj now in } \\
\text { Emtree }\end{array}$ & 0 & 0 & 0 & Retain \\
\hline $\begin{array}{l}\text { Line } 4 \\
\text { (corona* adj1 } \\
\text { pandemic*) }\end{array}$ & 9 & 8 & 1 & Reject \\
\hline $\begin{array}{l}\text { Line } 5 \\
\text { coron?virus*.ti,ab,kw }\end{array}$ & 1 & 1 & 0 & Reject \\
\hline $\begin{array}{l}\text { Line } 6 \\
\text { NOT CoV terms }\end{array}$ & -161 & 0 & 0 & Retain \\
\hline $\begin{array}{l}\text { Line } 6 \\
\text { NOT additional CoV } \\
\text { terms }\end{array}$ & -162 & 0 & 0 & Retain \\
\hline $\begin{array}{l}\text { Line } 7 \\
\text { Remove variants of } \mathrm{nCoV}\end{array}$ & 0 & 0 & 0 & Retain \\
\hline $\begin{array}{l}\text { Line } 8 \\
\text { Add COVID2019 }\end{array}$ & 0 & 0 & 0 & Reject \\
\hline $\begin{array}{l}\text { Line } 8 \\
\text { COVID* }\end{array}$ & 139 & 7 & 2 & Reject \\
\hline $\begin{array}{l}\text { Line } 8 \\
\text { COVID*2 }\end{array}$ & 4 & 3 & 2 & Retain \\
\hline $\begin{array}{l}\text { Line } 8 \\
\text { COVID*2 remove } \\
\text { COVID19 }\end{array}$ & 0 & 0 & 0 & Retain \\
\hline $\begin{array}{l}\text { Line } 9 \\
\text { "n-cov*" }\end{array}$ & 8 & 0 & 0 & Reject \\
\hline $\begin{array}{l}\text { Line } 9 \\
\text { Ncov without truncation }\end{array}$ & 2 & 2 & 1 & Reject \\
\hline
\end{tabular}


medRxiv preprint doi: https://doi.org/10.1101/2021.06.11.21258749; this version posted June 14, 2021. The copyright holder for this preprint (which was not certified by peer review) is the author/funder, who has granted medRxiv a license to display the preprint in perpetuity.

It is made available under a CC-BY 4.0 International license .

\section{Simplifying the refined Strategy $C$}

The revisions in Tables 10-11 were tested individually to judge their incremental impact. The refinements to be retained in the recommended version were consolidated into a single strategy. The terms were then condensed into as few lines as possible to make the strategy easier to run. The final strategy is presented in Figure 4 for MEDLINE and Figure 5 for Embase.

The baseline MEDLINE Strategy A (Appendix D) contained two exploded MeSH headings and 103 free-text clauses over 25 lines. The recommended MEDLINE strategy (Figure 4) includes two MeSH headings and 15 free-text clauses over four lines. The recommended strategy combines 14 free-text phrases relating to CoV with the NOT operator to increase specificity. The recommended strategy is simpler to use as it contains one adjacency operator, compared to nine in Strategy A.

Embase has also been simplified in Figure 5 (the free text matches MEDLINE). Three Emtree headings (one exploded) have replaced the two exploded headings and two phrases used in the subject heading (.sh) and proposed candidate (.dj) fields.

Compared to the baseline Strategy $\mathrm{A}$, the recommended strategy reduced the MEDLINE results from 94,170 to 93,844 and Embase from 82,957 to 82,513 with limits applied (Table 12). This increase in specificity from Strategy A has been achieved with the loss of only one reference of minimal relevance to NICE that does not directly refer to COVID-19 (Cournoyer et al., 2021).

Table 12. MEDLINE and Embase. Comparison of Strategy A with the recommended strategy (13 April 2021)

\begin{tabular}{|l|r|r|r|r|}
\hline \multirow{2}{*}{ Search strategy } & \multicolumn{2}{|c|}{ MEDLINE } & \multicolumn{2}{c|}{ Embase } \\
\cline { 2 - 5 } & Full search & Limits applied & \multicolumn{1}{c|}{ Full search } & Limits applied \\
\hline $\begin{array}{l}\text { Ovid COVID-19 } \\
\text { Limit }\end{array}$ & 126021 & 93583 & 124524 & 82271 \\
\hline Strategy A & 146633 & 94170 & 150443 & 82957 \\
\hline Strategy C & 145820 & 94041 & 149630 & 82868 \\
\hline $\begin{array}{l}\text { Recommended } \\
\text { strategy }\end{array}$ & 138969 & 93844 & 139502 & 82513 \\
\hline
\end{tabular}


medRxiv preprint doi: https://doi.org/10.1101/2021.06.11.21258749; this version posted June 14, 2021. The copyright holder for this preprint (which was not certified by peer review) is the author/funder, who has granted medRxiv a license to display the preprint in perpetuity.

\section{Discussion}

The recommended NICE COVID-19 search strategy is presented in Figures 4-5. This section discusses the decisions that were made to optimise the specificity of the search strategy, without affecting recall of references relevant to NICE.

\section{Importance of free-text terms}

The steps undertaken in this paper have updated the NICE COVID-19 search strategy to increase its specificity and to make it easier to run. Whilst the WHO have helped to stabilise the use of terminology (as reflected in the subject headings included in the strategy), the free-text demonstrates that a variety of terms continue to be used to refer to COVID-19.

The strategy must include sensitive free-text terms to capture relevant references that have not been indexed. For example, one of the earliest references about the pandemic (Lu, Stratton, \& Tang, 2020) was published on 16 January 2020 and added to Ovid MEDLINE on 18 January 2020 but had not been indexed as of 22 April 2021. Lu et al. (2020) has been indexed on Embase with the Emtree heading "Pneumonia". NICE would have missed 673 relevant references from MEDLINE (Table 3) and 48 from Embase (Table 4) in December 2020 without the free-text line for COVID-19.

\section{Evolution of language}

The continual development of the COVID-19 strategy demonstrates the evolution of language within the health sector. When developing search strategies, it is important to capture scientific terms as well as broader terms. However, some potentially relevant free-text terms and subject headings can generate noise and reduce the specificity of the strategy. The term "pandemic", for instance, has been used throughout the past year. COVID-19 is the first pandemic affecting some countries in a century, while other countries have more recent experience, for instance with H1N1 in 2009 (Fineberg, 2014). Pandemic preparedness was also discussed before the COVID-19 outbreak (Moon et al., 2015). Therefore, it is difficult to distinguish references discussing past pandemics (Shearer, Moss, McVernon, Ross, \& 
medRxiv preprint doi: https://doi.org/10.1101/2021.06.11.21258749; this version posted June 14, 2021. The copyright holder for this preprint (which was not certified by peer review) is the author/funder, who has granted medRxiv a license to display the preprint in perpetuity.

It is made available under a CC-BY 4.0 International license .

McCaw, 2020) from articles referring to the COVID-19 pandemic (da Silva et al., 2020; Smiianov et al., 2020) when no other identifiers have been included in the title or abstract. On this basis, the term "pandemic" was not included in the strategy as the aim of the update was to increase specificity. The references screened for this paper that referred to "the pandemic" seemed to refer to events that had happened since January 2020, rather than being about the clinical condition COVID-19 or the virus SARS-CoV-2. The issue requires further investigation.

Similarly, some references relied on country-specific phrases. For instance "protect the NHS" (Hunter, 2020) and "test and trace" (Harding-Edgar, McCartney, \& Pollock, 2020) are specific UK terms relating to the COVID-19 pandemic. These references were not retrieved by the final strategy as the title and abstracts did not contain terminology unique to COVID-19. References that use phrases specific to a country, without including COVID19 terms, rely on people inferring the context of the article. These references were not relevant to the NICE remit, although they do highlight an interesting challenge with terminology. A solution could be found in creating an additional search strategy, using localised terms in conjunction with a geographical search filter to capture relevant additional literature, but this would require further exploration.

\section{Spelling and formatting issues}

When screening the results found by the Ovid COVID-19 Limit for Tables 6-7, the authors found potentially relevant references that were missed due to spelling errors, for instance, "coronvirus" (Chen et al., 2020) or "Sarss-Cov2" (Angel Mejia, Arango Isaza, Fernandez Turizo, Vasquez Trespalacios, \& Rincon, 2021).

Formatting issues were also identified, such as: "COVIDSafe thoracic surgery" (Seco, Wood, \& Wilson, 2020) which was not retrieved because "COVID" and "Safe" were not separated by a space. Other papers were missed due to the creation of new (and unique) terminology, for instance "covidology" (Goldfarb, 2021), "covidization" (Pai, 2020) and "\#COVIDZero" (Vogel, 2020). Given that the terms were unique to these specific references, 
medRxiv preprint doi: https://doi.org/10.1101/2021.06.11.21258749; this version posted June 14, 2021. The copyright holder for this preprint (which was not certified by peer review) is the author/funder, who has granted medRxiv a license to display the preprint in perpetuity.

It is made available under a CC-BY 4.0 International license .

the strategy was not amended to retrieve them. Unlimited truncation was not appropriate to maintaining specificity. There would be scope for organisations needing more sensitive searches than NICE to explore these terms further. Note that three of these references have subsequently been indexed with headings that are retrieved by the NICE strategy (Chen et al., 2020; Seco et al., 2020; Vogel, 2020).

\section{Truncation}

The strategy includes the free-text term "COVID*2". The term is truncated to retrieve records that mention either the term COVID or variations of the term with up to two additional characters (e.g. letters, punctuation marks or numbers). Therefore, terms such as "COVID", "COVID19" and "COVID-19" are captured. Terms such as "Covidence" (a systematic-review tool) or "Covidien" (a company) are not retrieved by the strategy to maintain specificity. Testing showed that this approach retrieved the appropriate references, while reducing the number of free-text terms in the strategy.

\section{Related conditions}

During development, it was decided that terms for related named conditions (e.g. multisystem inflammatory syndrome, cytokine storm and Kawasaki disease) would not be included in the strategy. This was because the conditions are not triggered, exclusively, by COVID-19. The strategy retrieves references to secondary diseases linked to COVID-19 (Rubens, Akindele, Tschudy, \& Sick-Samuels, 2021). It does not retrieve references, outside of the NICE remit, that do not state a link to COVID-19 (Shenker, Trogen, Schroeder, Ratner, \& Kahn, 2020).

\section{Other coronaviruses}

The purpose of the strategy is to retrieve references on COVID-19 rather than other coronaviruses, such as Middle East Respiratory Syndrome coronavirus (MERS) or Severe Acute Respiratory Syndrome coronavirus 1 (SARS-CoV1). The Ovid COVID-19 Limit deliberately excludes references that focus on MERS (Killerby, Biggs, Midgley, Gerber, \& Watson, 2020; Mohamed, Aleanizy, Alqahtani, Alanazi, \& Mohamed, 2020) or SARS-Cov-1 using the 
medRxiv preprint doi: https://doi.org/10.1101/2021.06.11.21258749; this version posted June 14, 2021. The copyright holder for this preprint (which was not certified by peer review) is the author/funder, who has granted medRxiv a license to display the preprint in perpetuity.

It is made available under a CC-BY 4.0 International license .

NOT operator. This approach was not adopted for the NICE search strategy, as it risks missing references comparing MERS and/or SARs-CoV-1 with COVID-19 (Ather, Mirza, \& Edemekong, 2020).

One of the changes between the baseline Strategy $A$ and the recommended strategies in Figures 4-5 is that subject headings from lower in the hierarchy are used, for example "SARS-CoV-2" and "COVID-19" instead of exploding "Coronavirinae" or "Coronavirus infection". This increases specificity by reducing the number of results about other coronaviruses such as MERS, feline coronavirus (Takano, Satoh, \& Doki, 2021) or porcine delta coronavirus (Gao et al., 2020). Consequently, the strategy does not retrieve references on MERS, SARS-CoV-1 or animal coronaviruses outside of the NICE remit, but it does allow for references that discuss them with COVID-19 to be retrieved.

\section{Date limit}

The NICE COVID-19 search strategy is limited by publication year, to retrieve references from 1 January 2020 to present day. This date range was used as references published prior to this date would not focus on COVID-19. The date limit reduces the number of irrelevant references retrieved on other types of coronavirus.

\section{References reporting the initial outbreak in January 2020}

The original search strategy, based on the list in Appendix A, included terms relating to the outbreak of COVID-19 in Wuhan, as the very first papers had broad titles and were difficult to locate with any accuracy, such as "Outbreak of pneumonia of unknown etiology in Wuhan, China" (Lu et al., 2020) or "Mysterious pneumonia in China" (Bagcchi, 2020). The recommended strategy (Figures 4-5) no longer uses free-text terms relating to respiratory symptoms in Wuhan or seafood markets in China. As Tables 1-4 show, they were not necessary to retrieve references relevant to the NICE remit. Organisations that need to retrieve references published before the WHO's naming convention in February 2020 (World Health Organization, 2020) may want to test whether any of this free text should be retained. Some of these references may now have been indexed with the current subject headings. 
medRxiv preprint doi: https://doi.org/10.1101/2021.06.11.21258749; this version posted June 14, 2021. The copyright holder for this preprint (which was not certified by peer review) is the author/funder, who has granted medRxiv a license to display the preprint in perpetuity.

It is made available under a CC-BY 4.0 International license .

\section{Limitations and further research}

\section{Validation}

The strategy in Figures 4-5 has not been validated against an external gold standard, as would be expected of a search filter (Jenkins, 2004). Validation against a gold standard should be undertaken to test how the strategy performs against an independent set of references, once the pandemic has reached a stage where this would be appropriate.

\section{Screening process}

The screening that has been undertaken for this update was done by the same information specialists that developed the strategy. For example, when screening the references to create Tables 5-11 the authors were aware whether marking a reference as relevant would favour the Ovid COVID-19 Limit or NICE strategy. To balance this, all references were double screened. It was not in the authors' interests to create a filter that would either miss relevant references or unnecessarily reduce specificity for NICE.

The data for Tables 1-4 was collected in December 2020 and for Table 12 in April 2021. This means that the annual Ovid reload of data took place during the testing. Some of the testing might have different results if it were repeated after the reload.

\section{NICE remit}

The tests were run using the same limits that NICE applies when developing and monitoring its rapid guidelines. Using the language, format and animal study limits may have affected retrieval of references that other organisations would find relevant. The date limit has been used to restrict retrieval of references pre-dating this pandemic that are about other coronavirus infections, rather than COVID-19.

The MeSH 2021 terms for "COVID-19 testing" and "COVID-19 vaccines" were not included in this strategy as neither topic is within the remit of NICE. Terms on testing and vaccines would be considered for specific searches on these topics if NICE were to cover them. 
medRxiv preprint doi: https://doi.org/10.1101/2021.06.11.21258749; this version posted June 14, 2021. The copyright holder for this preprint (which was not certified by peer review) is the author/funder, who has granted medRxiv a license to display the preprint in perpetuity.

It is made available under a CC-BY 4.0 International license .

\section{Long COVID}

NICE has published a rapid guideline on managing the long-term effects of COVID-19 (often described as "long COVID") and "post-COVID-19 syndrome" (NICE, 2020a). Figures 4-5 are not optimised for long COVID or post-COVID19 syndrome, which require a multi-stranded approach and additional free text. The searches have been described in detail elsewhere (NICE, 2020d).

\section{Variants of Concern and Variants of Interest}

There has been international concern about the risks from variants of the SARS-CoV-2 virus (Mahase, 2021), such as variant VOC202101/02, the N501Y mutation and variant 501Y.V2. This is felt to be a low risk as references would be expected to refer to variations or mutations of SARSCoV-2 (or COVID-19). It is plausible that a reference without an abstract could have a title referring to, say, "Treating VOC202101/02". However, there are no specific MeSH headings for SARS-CoV-2 variants. At present, any MEDLINE references should be indexed with the subject headings used in Figure 4.

The Emtree heading "Severe acute respiratory syndrome coronavirus 2" has been exploded in Figure 5 and this should capture the current variants listed in Emtree and any that are added in the future.

Figures 4-5 have not been tested for retrieval of references on these variants or mutations, although the authors have not identified any papers that would be missed. The naming conventions for SARS-CoV-2 Variants of Concern and Variants of Interest were announced on 31 May 2021 (World Health Organization, 2021) and should provide consistency in this area. The terminology should be monitored as new variants continue to be identified.

\section{Search fields}

The search fields for the free-text lines were consistent throughout development of the strategies in Figures 4-5. The fields used were the title (.ti), abstract (.ab), keyword heading (.kw) and, for MEDLINE, keyword heading word (.kf). These fields were chosen in March 2020 when there was 
medRxiv preprint doi: https://doi.org/10.1101/2021.06.11.21258749; this version posted June 14, 2021. The copyright holder for this preprint (which was not certified by peer review) is the author/funder, who has granted medRxiv a license to display the preprint in perpetuity.

It is made available under a CC-BY 4.0 International license .

a lack of published information and terminology had not been established. It is acknowledged that additional testing could be done to confirm that the fields selected are the most appropriate. Further exploration would also be required to assess if additional fields would have a positive and meaningful impact on the strategy.

\section{Search sources}

The contribution of MEDLINE and Embase to NICE rapid guidelines has not been assessed and it is assumed that they will still be searched. NICE has continued to search individual sources rather than relying on curated collections. The first evaluation of the Cochrane COVID-19 Study Register (Metzendorf \& Featherstone, 2021) has demonstrated promising results for curated collections. It would be worth exploring whether the comprehensiveness, accuracy, and currency of these collections meets the needs of NICE. A key issue for NICE is ensuring timely access to pre-prints. It is hoped that the discussion in this paper can inform the search strategies being used to populate curated sources.

\section{Conclusions}

The strategy is designed specifically for COVID-19 references relevant to NICE. The strategy could be validated against a gold standard at an appropriate point in the pandemic.

The strategy is not intended to be prescriptive, and its appropriateness would need to be reviewed before being used by other organisations. This detailed description of how the strategy has been developed and maintained is intended to highlight common issues that expert searchers are likely to encounter. Additional strategies could be created to retrieve a broader set of results, for example to capture localised terminology (e.g. "track and trace"), general pandemic preparedness, serological testing or vaccinations.

The free-text terms and subject headings used in the NICE baseline strategy have been updated to make it easier to run and improve specificity. The recommended NICE COVID-19 search strategy to retrieve references relevant to NICE from Ovid MEDLINE and Embase is now available for use. 


\section{Figure 4. Recommended NICE COVID-19 search strategy for Ovid MEDLINE}

1 SARS-CoV-2/ or COVID-19/

2 (corona* adj1 (virus* or viral*)).ti,ab,kw,kf.

3 (CoV not (Coefficien* or "co-efficien*" or covalent* or Covington* or covariant* or covarianc* or "cut-off value*" or "cutoff value*" or "cut-off volume*" or "cutoff volume*" or "combined optimi?ation value*" or "central vessel trunk*" or CoVR or CoVS)).ti,ab,kw,kf.

4 (coronavirus* or $2019 n \mathrm{nCoV}^{*}$ or $19 \mathrm{nCoV*}$ or "2019 novel*" or Ncov* or "n-cov" or "SARSCoV-2*" or "SARSCoV-2*" or SARSCoV2* or "SARS-CoV2*" or "severe acute respiratory syndrome*" or COVID*2).ti,ab,kw,kf.

5 or/1-4

6 limit 5 to $y r=" 2020-C u r r e n t "$

7 (6 and english.lg.) not (letter or historical article or comment or editorial or news).pt. not (Animals/ not humans/)

Note:

- The limits on line 7 are optional.

- $\quad$ The strategy is designed for the NICE remit on COVID-19.

- It does not include MeSH headings "exp COVID-19 Testing" or "COVID-19 Vaccines".

- This is not configured for Long Covid, which should be searched separately.

- It does not aim to cover comprehensively other coronaviruses (such as MERS or SARSCoV-1). 


\section{Figure 5. Recommended NICE COVID-19 search strategy for Ovid}

\section{Embase}

1 exp severe acute respiratory syndrome coronavirus 2/ or coronavirus disease 2019/ or experimental coronavirus disease 2019/

2 (corona* adj1 (virus* or viral*)).ti,ab,kw.

3 (CoV not (Coefficien* or co-efficien* or covalent* or covington or covariant* or covarianc* or "cut-off value*" or "cutoff value*" or "cut-off volume*" or "cutoff volume*" or "combined optimi?ation value*" or "central vessel trunk" or CoVR or CoVS)).ti,ab,kw.

4 (coronavirus* or $2019 n \mathrm{CoV}^{*}$ or $19 \mathrm{nCoV} *$ or "2019 novel*" or Ncov* or "n-cov" or "SARSCoV-2*" or "SARSCOV-2*" or SARSCoV2* or "SARS-CoV2*" or "severe acute respiratory syndrome*" or COVID*2).ti,ab,kw.

5 or $/ 1-4$

6 limit 5 to $y r=" 2020$-Current"

7 (6 and english.lg.) not (letter or editorial).pt. not (nonhuman/ not human/) not (conference abstract or conference paper or conference proceeding or "conference review").pt.

Note:

- The limits on line 7 are optional.

- The strategy is designed for the NICE remit on COVID-19.

- This is not configured for Long Covid, which should be searched separately.

- It does not aim to cover comprehensively other coronaviruses (such as MERS or SARSCoV-1). 
medRxiv preprint doi: https://doi.org/10.1101/2021.06.11.21258749; this version posted June 14, 2021. The copyright holder for this preprint (which was not certified by peer review) is the author/funder, who has granted medRxiv a license to display the preprint in perpetuity.

\section{References}

Angel Mejia, V. E., Arango Isaza, D., Fernandez Turizo, M. J., Vasquez Trespalacios, E. M., \& Rincon, J. A. (2021). High flow nasal cannula useful for severe SARSs-CoV-2 pneumonia. Medicina Intensiva. https://doi.org/10.1016/j.medin.2021.01.002

Ather, B., Mirza, T. M., \& Edemekong, P. F. (2020). Airborne Precautions. Retrieved from https://www.ncbi.nlm.nih.gov/books/NBK531468/

Bagcchi, S. (2020). Mysterious pneumonia in China. The Lancet. Infectious Diseases, 20(2), 173. https://doi.org/10.1016/S1473-3099(20)30011-6

Chen, J., Tian, C., Cheng, X., Huang, Y., Tang, L., Wang, R., \& Zeng, X. (2020). A Case of Coronvirus Disease 2019 with Psychological Disorders. Psychiatria Danubina, 32(34), 581-583. https://doi.org/10.24869/psyd.2020.581

Cournoyer, A., Grand'Maison, S., Lonergan, A.-M., Lessard, J., Chauny, J.M., Castonguay, V., ... Daoust, R. (2021). Oxygen Therapy and Risk of Infection for Health Care Workers Caring for Patients With Viral Severe Acute Respiratory Infection: A Systematic Review and Meta-analysis. Annals of Emergency Medicine, 77(1), 19-31. https://doi.org/10.1016/j.annemergmed.2020.06.037

da Silva, C. F., Deutschendorf, C., Nagel, F. M., Dalmora, C. H., Dos Santos, R. P., \& Lisboa, T. C. (2020). Impact of the pandemic on antimicrobial consumption patterns. Infection Control and Hospital Epidemiology, 1-3. https://doi.org/10.1017/ice.2020.1227

Elsevier. (2021). Emtree terms added and changed (January 2021). Retrieved from http://supportcontent.elsevier.com/RightNow Next Gen/Embase/Emtree terms added and changed 2021 V1.pdf

Fineberg, H. V. (2014). Pandemic Preparedness and Response - Lessons from the H1N1 Influenza of 2009. New England Journal of Medicine, 370(14), 1335-1342. https://doi.org/10.1056/NEJMra1208802 
medRxiv preprint doi: https://doi.org/10.1101/2021.06.11.21258749; this version posted June 14, 2021. The copyright holder for this preprint (which was not certified by peer review) is the author/funder, who has granted medRxiv a license to display the preprint in perpetuity.

It is made available under a CC-BY 4.0 International license .

Gao, X., Zhang, L., Zhou, P., Zhang, Y., Wei, Y., Wang, Y., \& Liu, X. (2020). Tandem Mass Tag-Based Quantitative Proteome Analysis of Porcine Deltacoronavirus (PDCoV)-Infected LLC Porcine Kidney Cells. ACS Omega, 5(35), 21979-21987. https://doi.org/10.1021/acsomega.0c00886

Goldfarb, D. S. (2021). Editorial: Controversies in nephrologic covidology. Current Opinion in Nephrology and Hypertension, 30(2), 173-175. https://doi.org/10.1097/mnh.0000000000000685

Harding-Edgar, L., McCartney, M., \& Pollock, A. M. (2020). Test and trace strategy has overlooked importance of clinical input, clinical oversight and integration. Journal of the Royal Society of Medicine, 113(11), 428-432. https://doi.org/10.1177/0141076820967906

Hunter, D. J. (2020). Trying to "Protect the NHS" in the United Kingdom. New England Journal of Medicine, 383(25), e136. https://doi.org/10.1056/nejmp2032508

Jenkins, M. (2004). Evaluation of methodological search filters-a review. Health Information \& Libraries Journal, 21(3), 148-163. https://doi.org/10.1111/j.1471-1842.2004.00511.x

Killerby, M. E., Biggs, H. M., Midgley, C. M., Gerber, S. I., \& Watson, J. T. (2020). Middle East Respiratory Syndrome Coronavirus Transmission. Emerging Infectious Diseases, 26(2), 191-198. https://doi.org/10.3201/eid2602.190697

Lazarus, J. V, Palayew, A., Rasmussen, L. N., Andersen, T. H., Nicholson, J., \& Norgaard, O. (2020). Searching PubMed to Retrieve Publications on the COVID-19 Pandemic: Comparative Analysis of Search Strings. Journal of Medical Internet Research, 22(11), e23449. https://doi.org/10.2196/23449

Lu, H., Stratton, C. W., \& Tang, Y. (2020). Outbreak of pneumonia of unknown etiology in Wuhan, China: The mystery and the miracle. Journal of Medical Virology, 92(4), 401-402. https://doi.org/10.1002/jmv.25678 
medRxiv preprint doi: https://doi.org/10.1101/2021.06.11.21258749; this version posted June 14, 2021. The copyright holder for this preprint (which was not certified by peer review) is the author/funder, who has granted medRxiv a license to display the preprint in perpetuity.

It is made available under a CC-BY 4.0 International license .

Mahase, E. (2021). Covid-19: What new variants are emerging and how are they being investigated? BMJ, 372, n158. https://doi.org/10.1136/bmj.n158

McGowan, J., Sampson, M., Salzwedel, D. M., Cogo, E., Foerster, V., \& Lefebvre, C. (2016). PRESS Peer Review of Electronic Search Strategies: 2015 Guideline Statement. Journal of Clinical Epidemiology, 75, 40-46. https://doi.org/10.1016/J.JCLINEPI.2016.01.021

Metzendorf, M.-I., \& Featherstone, R. M. (2021). Evaluation of the sensitivity, accuracy and currency of the Cochrane COVID-19 Study Register for supporting rapid evidence synthesis production. MedRxiv, 2021.04.21.21255874. https://doi.org/10.1101/2021.04.21.21255874

Mohamed, R. A. E. H., Aleanizy, F. S., Alqahtani, F. Y., Alanazi, M. S., \& Mohamed, N. (2020). Common Co-morbidities Are Challenging in the Diagnosis of Middle East Respiratory Syndrome (MERS-CoV) in Saudi Arabia. Pakistan Journal of Biological Sciences : PJBS, 23(2), 119-125. https://doi.org/10.3923/pjbs.2020.119.125

Moon, S., Sridhar, D., Pate, M. A., Jha, A. K., Clinton, C., Delaunay, S., ... Piot, P. (2015). Will Ebola change the game? Ten essential reforms before the next pandemic. the report of the Harvard-LSHTM Independent Panel on the Global Response to Ebola. The Lancet, 386(10009), 22042221. https://doi.org/10.1016/S0140-6736(15)00946-0

National Library of Medicine. (2020). What's New in MeSH. Retrieved from https://www.nlm.nih.gov/mesh/whatsnew.html

NICE. (2020a). COVID-19 rapid guideline: managing the long-term effects of COVID-19. NICE guideline 188. Retrieved from https://www.nice.org.uk/guidance/ng188

NICE. (2020b). Developing NICE guidelines: the manual. Appendix L: Interim process and methods for guidelines developed in response to health and social care emergencies. Retrieved from 
medRxiv preprint doi: https://doi.org/10.1101/2021.06.11.21258749; this version posted June 14, 2021. The copyright holder for this preprint (which was not certified by peer review) is the author/funder, who has granted medRxiv a license to display the preprint in perpetuity.

It is made available under a CC-BY 4.0 International license .

https://www.nice.org.uk/process/pmg20/resources/appendix-l-interimprocess-and-methods-for-guidelines-developed-in-response-to-healthand-social-care-emergencies-8779776589/chapter/rapid-updating-of-thehealth-and-social-care-emergency-guideline

NICE. (2020c). Developing NICE guidelines: the manual. Retrieved from https://www.nice.org.uk/process/pmg20/chapter/introduction

NICE. (2020d). MEDLINE (Ovid) search strategy for managing the long-term effects of COVID-19. Retrieved from https://kfh.libraryservices.nhs.uk/covid-19-coronavirus/for-lksstaff/literature-searches/

NICE. (2020e). Research to access pathway for investigational drugs for COVID-19 (RAPID-C19). Retrieved from https://www.nice.org.uk/covid19/rapid-c19

NICE. (2021). Coronavirus (COVID-19). Guidelines about COVID-19. Retrieved from https://www.nice.org.uk/covid-19

Pai, M. (2020). Author Correction: Covidization of research: what are the risks?. Nature Medicine, 26(11), 1801. https://doi.org/10.1038/s41591020-1127-6

Public Health England. (2021). Finding the evidence: Coronavirus. Retrieved from https://phelibrary.koha-ptfs.co.uk/coronavirusinformation/

Rubens, J. H., Akindele, N. P., Tschudy, M. M., \& Sick-Samuels, A. C. (2021). Acute covid-19 and multisystem inflammatory syndrome in children. BMJ, 372, n385. https://doi.org/10.1136/bmj.n385

Seco, M., Wood, J., \& Wilson, M. K. (2020). COVIDSafe thoracic surgery: Minimizing intraoperative exposure to aerosols. JTCVS Techniques, 3, 412-414. https://doi.org/10.1016/j.xjtc.2020.05.017

Seghatchian, J. (2021). New generation of vaccines and convalescent plasma therapy for management of CoV-2: Perspectives from the UK and 
medRxiv preprint doi: https://doi.org/10.1101/2021.06.11.21258749; this version posted June 14, 2021. The copyright holder for this preprint (which was not certified by peer review) is the author/funder, who has granted medRxiv a license to display the preprint in perpetuity.

It is made available under a CC-BY 4.0 International license .

potential deployment in the current global pandemic. Transfusion and Apheresis Science, 103051. https://doi.org/10.1016/j.transci.2021.103051

Shearer, F. M., Moss, R., McVernon, J., Ross, J. V, \& McCaw, J. M. (2020). Infectious disease pandemic planning and response: Incorporating decision analysis. PLoS Medicine, 17(1), e1003018. https://doi.org/10.1371/journal.pmed.1003018

Shenker, J., Trogen, B., Schroeder, L., Ratner, A. J., \& Kahn, P. (2020). Multisystem Inflammatory Syndrome in Children Associated with Status Epilepticus. The Journal of Pediatrics, 227, 300-301.

https://doi.org/10.1016/j.jpeds.2020.07.062

Shokraneh, F., \& Russell-Rose, T. (2020). Lessons from COVID-19 to future evidence synthesis efforts: first living search strategy and out of date scientific publishing and indexing industry. Journal of Clinical Epidemiology, 123, 171-173.

https://doi.org/10.1016/j.jclinepi.2020.04.014

Smiianov, V. A., Lyulyov, O. V, Pimonenko, T. V, Andrushchenko, T. A., Sova, S., \& Grechkovskaya, N. V. (2020). The impact of the pandemic lockdown on air pollution, health and economic growth: system dynamics analysis. Wiadomosci Lekarskie, 73(11), 2332-2338.

Southall, S., Taske, N., Power, E., Desai, M., \& Baillie, N. (2021). Spotlight on COVID-19 rapid guidance: NICE's experience of producing rapid guidelines during the pandemic. Journal of Public Health, 43(1), e103e106. https://doi.org/10.1093/pubmed/fdaa184

Takano, T., Satoh, K., \& Doki, T. (2021). Possible Antiviral Activity of 5Aminolevulinic Acid in Feline Infectious Peritonitis Virus (Feline Coronavirus) Infection. Frontiers in Veterinary Science, 8, 647189. https://doi.org/10.3389/fvets.2021.647189

Teixeira da Silva, J. A., Tsigaris, P., \& Erfanmanesh, M. (2021). Publishing volumes in major databases related to Covid-19. Scientometrics, 126(1), 
medRxiv preprint doi: https://doi.org/10.1101/2021.06.11.21258749; this version posted June 14, 2021. The copyright holder for this preprint (which was not certified by peer review) is the author/funder, who has granted medRxiv a license to display the preprint in perpetuity.

It is made available under a CC-BY 4.0 International license.

831-842. https://doi.org/10.1007/s11192-020-03675-3

Tian, X., Li, C., Huang, A., Xia, S., Lu, S., Shi, Z., ... Ying, T. (2020). Potent binding of 2019 novel coronavirus spike protein by a SARS coronavirusspecific human monoclonal antibody. Emerging Microbes and Infections, 9(1), 382-385. https://doi.org/10.1080/22221751.2020.1729069

Vogel, L. (2020). Should Canada aim for \#CovidZero?. CMAJ : Canadian Medical Association Journal = Journal de l'Association Medicale Canadienne, 192(50), e1814-e1815. https://doi.org/10.1503/cmaj.1095909

Wolters Kluwer. (2021a). Embase: Excerpta Medica Database Guide. Retrieved from https://ospguides.ovid.com/OSPguides/embase.htm

Wolters Kluwer. (2021b). MEDLINE 2021 Database Guide. Retrieved from https://ospguides.ovid.com/OSPguides/medline.htm

World Health Organization. (2020). Naming the coronavirus disease (COVID19) and the virus that causes it. Retrieved from https://www.who.int/emergencies/diseases/novel-coronavirus2019/technical-guidance/naming-the-coronavirus-disease-(covid-2019)and-the-virus-that-causes-it

World Health Organization. (2021). Tracking SARS-CoV-2 variants. Retrieved from https://www.who.int/en/activities/tracking-SARS-CoV-2-variants 


\section{Appendix A. Terms suggested by Public Health England on 16 March 2020}

\begin{tabular}{|l|}
\hline coronavirus \\
\hline Coronavirus Infections \\
\hline coronovirus \\
\hline CORVID-19 \\
\hline CoV \\
\hline COVID-19 \\
\hline HCoV-19 \\
\hline ncov \\
\hline ncov* wuhan \\
\hline new coronavirus \\
\hline novel coronavirus \\
\hline $\begin{array}{l}\text { (outbreak* OR "respiratory illness" OR "respiratory disease" OR respiratory symptom* OR } \\
\text { seafood market OR food market OR wildlife) and (Wuhan OR China OR Chinese) }\end{array}$ \\
\hline SARSCov19 \\
\hline SARS-CoV-2 \\
\hline WN-CoV \\
\hline Wuhan \\
\hline "Wuhan coronavirus" \\
\hline 2019 novel \\
\hline "2019-nCoV" \\
\hline
\end{tabular}




\section{Appendix B. Version history for the NICE COVID-19 search strategy for Ovid MEDLINE and Embase}

\begin{tabular}{|c|c|c|}
\hline Version & $\begin{array}{l}\text { Date } \\
\text { implemented }\end{array}$ & Actions \\
\hline $\mathrm{v} 1$ & 16 March 2020 & $\begin{array}{l}\text { Terms suggested by Public Health England added to Ovid } \\
\text { MEDLINE and Embase. }\end{array}$ \\
\hline v2 & 17 March 2020 & $\begin{array}{l}\text { Quality Assurance of v1: } \\
\text { - } \quad \text { Added the free-text term "epidemic". } \\
\text { - } \quad \text { Added the free-text term "Huanan" on the lines with the } \\
\text { term "Wuhan". } \\
\text { - } \quad \text { Replaced AND with adj10 to increase specificity on the } \\
\text { free-text line for "outbreak". } \\
\text { - Added a free-text line for the phrase "severe acute } \\
\text { respiratory syndrome*". } \\
\text { - Added the kw field as this is a new area where the } \\
\text { indexing is not up to date. }\end{array}$ \\
\hline v3 & 18 March 2020 & $\begin{array}{l}\text { Increased the precision as it was retrieving too many papers } \\
\text { on other epidemics in China (e.g. malaria): } \\
\text { - Split the lines on ("respiratory symptom*" or "seafood } \\
\text { market") from ("outbreak* or wildlife* or pandemic") so } \\
\text { that the adjacency could be made a lot narrower. }\end{array}$ \\
\hline v4 & 19 March 2020 & $\begin{array}{l}\text { This version was added to Appendix L of the Interim process } \\
\text { (NICE, 2020b): } \\
\text { - Identified and added the Emtree heading "Coronavirinae". } \\
\text { - Added "Coronavirinae" to the free text. } \\
\text { - Added "respiratory condition" to the free text and } \\
\text { remodelled this line. } \\
\text { - Made changes to the way that "Wuhan" and "Huanan" } \\
\text { were included as free-text terms. }\end{array}$ \\
\hline v5 & 21 March 2020 & $\begin{array}{l}\text { Identified an additional MeSH heading: } \\
\text { - Added Coronavirus Infections (and rechecked searches } \\
\text { completed 16-20 March). }\end{array}$ \\
\hline v6 & 25 March 2020 & $\begin{array}{l}\text { Made the strategy more specific following feedback it was still } \\
\text { over retrieving references about epidemics in China: } \\
\text { - Changed the position of "Wuhan" in the strategy but also } \\
\text { added "pneumonia" to the line on respiratory conditions. } \\
\text { - } \quad \text { Added the abbreviation "HCoV" for human coronaviruses } \\
\text { to the free text; small impact as the relevant subject } \\
\text { headings were already incorporated by exploding the } \\
\text { ones higher in the hierarchy. } \\
\text { - Identified that the .kf field would be a useful addition } \\
\text { following extensive testing in MEDLINE (it is not available } \\
\text { in Embase). } \\
\text { - Changed all MEDLINE free-text lines to .ti,ab,kw,kf }\end{array}$ \\
\hline v7 & 8 April 2020 & $\begin{array}{l}\text { No substantive changes but some free-text lines were } \\
\text { separated to make the strategy easier to read. }\end{array}$ \\
\hline v8 & 16 April 2020 & $\begin{array}{l}\text { Added terms to the free text for consistency: } \\
\text { - } \quad \text { nCoV19 or "nCoV-19" } \\
\text { - } \quad \text { "HCoV-19" or HCoV19. }\end{array}$ \\
\hline
\end{tabular}


medRxiv preprint doi: https://doi.org/10.1101/2021.06.11.21258749; this version posted June 14, 2021. The copyright holder for this preprint (which was not certified by peer review) is the author/funder, who has granted medRxiv a license to display the preprint in perpetuity.

It is made available under a CC-BY 4.0 International license .

\begin{tabular}{|c|c|c|}
\hline v9 & 3 June 2020 & $\begin{array}{l}\text { In-depth review of the free-text lines and the structure (see } \\
\text { Appendix C): } \\
\text { - Reviewed the free text terms used for "COVID-19" and } \\
\text { "SARS-CoV-2". } \\
\text { - Removed some of the free-text terms that had zero hits. } \\
\text { - Checked all lines for consistency, adding some truncation. } \\
\text { - Tested and decided not to add some additional terms that } \\
\text { had been identified, such as "Betacoronavirus". } \\
\text { - Changed the structure slightly to remove references on } \\
\text { pneumonia in China not relevant to this pandemic. }\end{array}$ \\
\hline v10 & 16 April 2021 & $\begin{array}{l}\text { Extensive testing of each free-text line. } \\
\text { Added new MeSH and Emtree headings now available in Ovid. } \\
\text { Detailed comparison to the Ovid COVID-19 Limit. } \\
\text { Complete restructuring to update the strategy. } \\
\text { The strategy: } \\
\text { - has been developed for the NICE remit on COVID-19. } \\
\text { - does not include the MeSH headings "exp COVID-19 } \\
\text { Testing" or "COVID-19 Vaccines". } \\
\text { - includes subject headings for "COVID-19" and "SARS-CoV- } \\
\text { 2" rather than exploding the terms from higher in the } \\
\text { hierarchy, as in previous versions. } \\
\text { - does not aim to cover comprehensively other } \\
\text { coronaviruses (such as MERS or SARS-CoV-1). } \\
\text { includes a publication date limit of } 2019 \text {-current to restrict } \\
\text { the number of references on other coronaviruses. } \\
\text { - has not been tested for retrieval of references about } \\
\text { variations of SARS-CoV-2 (no missing references } \\
\text { identified). } \\
\text { - uses COVID*2 to retrieve "COVID-19" and "COVID19" but } \\
\text { avoid retrieving terms such as "Covidence"; a small } \\
\text { number of references about COVID-19 that use unusual } \\
\text { terminology (e.g. "covidology") are not retrieved but none } \\
\text { - } \text { of them are relevant to NICE. } \\
\text { - } \text { is not optimised for Long COVID (see NICE, 2020a). } \\
\text { "Wuhan" and "food markets"; this does not affect } \\
\text { retrieval of references relevant to NICE but these terms } \\
\text { could be useful for references written in January } 2020 \\
\text { identifying the pandemic that have not been indexed. } \\
\text { activation Syndrome, Cytokine Release Syndrome and } \\
\text { Multisystem inflammatory syndrome. } \\
\text { coeficients of variation) that are abbreviated to CoV but } \\
\text { - }\end{array}$ \\
\hline
\end{tabular}




\section{Appendix C. Test used to create version 9 in June 2020}

\begin{tabular}{|c|c|c|c|}
\hline Status & Searches & $\begin{array}{l}\text { No. of results } \\
\text { retrieved from } \\
\text { Ovid MEDLINE } \\
\text { ALL } 1946 \text { to } \\
\text { May 19, } 2020\end{array}$ & Decision \\
\hline $\begin{array}{l}\text { Included in v8 } \\
\text { (April 2020) }\end{array}$ & "2019-nCoV".ti,ab,kw,kf. & 728 & $\begin{array}{l}\text { Retain - finds } \\
\text { references }\end{array}$ \\
\hline $\begin{array}{l}\text { Included in v8 } \\
\text { (April 2020) }\end{array}$ & 2019nCoV.ti,ab,kw,kf. & 3 & $\begin{array}{l}\text { Retain - finds } \\
\text { references }\end{array}$ \\
\hline $\begin{array}{l}\text { Included in v8 } \\
\text { (April 2020) }\end{array}$ & nCoV2019.ti,ab,kw,kf. & 4 & $\begin{array}{l}\text { Retain - finds } \\
\text { references }\end{array}$ \\
\hline $\begin{array}{l}\text { Included in v8 } \\
\text { (April 2020) }\end{array}$ & "nCoV-2019".ti,ab,kw,kf. & 38 & $\begin{array}{l}\text { Retain - finds } \\
\text { references }\end{array}$ \\
\hline $\begin{array}{l}\text { Included in v8 } \\
\text { (April 2020) }\end{array}$ & nCoV19.ti,ab,kw,kf. & 0 & $\begin{array}{l}\text { Retain -not found a } \\
\text { reference but variant } \\
\text { of a term that has }\end{array}$ \\
\hline $\begin{array}{l}\text { Included in v8 } \\
\text { (April 2020) }\end{array}$ & "nCoV-19".ti,ab,kw,kf. & 4 & $\begin{array}{l}\text { Retain - finds } \\
\text { references }\end{array}$ \\
\hline $\begin{array}{l}\text { Included in v8 } \\
\text { (April 2020) }\end{array}$ & "COVID-19".ti,ab,kw,kf. & 13338 & $\begin{array}{l}\text { Retain - finds } \\
\text { references }\end{array}$ \\
\hline $\begin{array}{l}\text { Included in v8 } \\
\text { (April 2020) }\end{array}$ & COVID19.ti,ab,kw,kf. & 179 & $\begin{array}{l}\text { Retain - finds } \\
\text { references }\end{array}$ \\
\hline $\begin{array}{l}\text { Included in v8 } \\
\text { (April 2020) }\end{array}$ & "CORVID-19".ti,ab,kw,kf. & 0 & $\begin{array}{l}\text { Remove - never found } \\
\text { a reference }\end{array}$ \\
\hline $\begin{array}{l}\text { Included in v8 } \\
\text { (April 2020) }\end{array}$ & CORVID19.ti,ab,kw,kf. & 0 & $\begin{array}{l}\text { Remove - never found } \\
\text { a reference }\end{array}$ \\
\hline $\begin{array}{l}\text { Included in v8 } \\
\text { (April 2020) }\end{array}$ & "WN-CoV".ti,ab,kw,kf. & 0 & $\begin{array}{l}\text { Remove - never found } \\
\text { a reference }\end{array}$ \\
\hline $\begin{array}{l}\text { Included in v8 } \\
\text { (April 2020) }\end{array}$ & WNCoV.ti,ab,kw,kf. & 0 & $\begin{array}{l}\text { Remove - never found } \\
\text { a reference }\end{array}$ \\
\hline $\begin{array}{l}\text { Included in v8 } \\
\text { (April 2020) }\end{array}$ & "HCoV-19".ti,ab,kw,kf. & 8 & $\begin{array}{l}\text { Retain - finds } \\
\text { references }\end{array}$ \\
\hline $\begin{array}{l}\text { Included in v8 } \\
\text { (April 2020) }\end{array}$ & HCoV19.ti,ab,kw,kf. & 0 & $\begin{array}{l}\text { Retain -not found a } \\
\text { reference but variant } \\
\text { of a term that has }\end{array}$ \\
\hline $\begin{array}{l}\text { Included in v8 } \\
\text { (April 2020) }\end{array}$ & "HCoV-2019".ti,ab,kw,kf. & 0 & $\begin{array}{l}\text { Retain -not found a } \\
\text { reference but variant } \\
\text { of a term that has }\end{array}$ \\
\hline $\begin{array}{l}\text { Included in v8 } \\
\text { (April 2020) }\end{array}$ & HCoV2019.ti,ab,kw,kf. & 0 & $\begin{array}{l}\text { Retain -not found a } \\
\text { reference but variant } \\
\text { of a term that has }\end{array}$ \\
\hline $\begin{array}{l}\text { Included in v8 } \\
\text { (April 2020) }\end{array}$ & "2019 novel*".ti,ab,kw,kf. & 648 & $\begin{array}{l}\text { Retain - finds } \\
\text { references }\end{array}$ \\
\hline $\begin{array}{l}\text { Included in v8 } \\
\text { (April 2020) }\end{array}$ & Ncov.ti,ab,kw,kf. & 762 & $\begin{array}{l}\text { Retain - finds } \\
\text { references }\end{array}$ \\
\hline $\begin{array}{l}\text { Included in v8 } \\
\text { (April 2020) }\end{array}$ & "n-cov".ti,ab,kw,kf. & 4 & $\begin{array}{l}\text { Retain - finds } \\
\text { references }\end{array}$ \\
\hline
\end{tabular}




\begin{tabular}{|c|c|c|c|}
\hline $\begin{array}{l}\text { Included in v8 } \\
\text { (April 2020) }\end{array}$ & "SARS-CoV-2".ti, ab,kw,kf. & 4153 & $\begin{array}{l}\text { Retain - finds } \\
\text { references }\end{array}$ \\
\hline $\begin{array}{l}\text { Included in v8 } \\
\text { (April 2020) }\end{array}$ & "SARSCoV-2".ti,ab,kw,kf. & 20 & $\begin{array}{l}\text { Retain - finds } \\
\text { references }\end{array}$ \\
\hline $\begin{array}{l}\text { Included in v8 } \\
\text { (April 2020) }\end{array}$ & "SARSCoV2".ti,ab,kw,kf. & 2 & $\begin{array}{l}\text { Retain - finds } \\
\text { references }\end{array}$ \\
\hline $\begin{array}{l}\text { Included in v8 } \\
\text { (April 2020) }\end{array}$ & "SARS-CoV2".ti,ab,kw,kf. & 202 & $\begin{array}{l}\text { Retain - finds } \\
\text { references }\end{array}$ \\
\hline $\begin{array}{l}\text { Included in v8 } \\
\text { (April 2020) }\end{array}$ & SARSCov19.ti,ab,kw,kf. & 0 & $\begin{array}{l}\text { Retain -not found a } \\
\text { reference but variant } \\
\text { of a term that has }\end{array}$ \\
\hline $\begin{array}{l}\text { Included in v8 } \\
\text { (April 2020) }\end{array}$ & "SARS-Cov19".ti,ab,kw,kf. & 0 & $\begin{array}{l}\text { Retain -not found a } \\
\text { reference but variant } \\
\text { of a term that has }\end{array}$ \\
\hline $\begin{array}{l}\text { Included in v8 } \\
\text { (April 2020) }\end{array}$ & "SARSCov-19".ti,ab,kw,kf. & 0 & $\begin{array}{l}\text { Retain -not found a } \\
\text { reference but variant } \\
\text { of a term that has }\end{array}$ \\
\hline $\begin{array}{l}\text { Included in v8 } \\
\text { (April 2020) }\end{array}$ & "SARS-Cov-19".ti,ab,kw,kf. & 6 & $\begin{array}{l}\text { Retain - finds } \\
\text { references }\end{array}$ \\
\hline $\begin{array}{l}\text { Included in v8 } \\
\text { (April 2020) }\end{array}$ & Ncovor.ti,ab,kw,kf. & 0 & $\begin{array}{l}\text { Remove - never found } \\
\text { a reference }\end{array}$ \\
\hline $\begin{array}{l}\text { Included in v8 } \\
\text { (April 2020) }\end{array}$ & Ncorona*.ti,ab,kw,kf. & 0 & $\begin{array}{l}\text { Remove - never found } \\
\text { a reference }\end{array}$ \\
\hline $\begin{array}{l}\text { Included in v8 } \\
\text { (April 2020) }\end{array}$ & Ncorono*.ti,ab,kw,kf. & 0 & $\begin{array}{l}\text { Remove - never found } \\
\text { a reference }\end{array}$ \\
\hline $\begin{array}{l}\text { Included in v8 } \\
\text { (April 2020) }\end{array}$ & NcovWuhan*.ti,ab,kw,kf. & 0 & $\begin{array}{l}\text { Remove - never found } \\
\text { a reference }\end{array}$ \\
\hline $\begin{array}{l}\text { Included in v8 } \\
\text { (April 2020) }\end{array}$ & NcovHubei*.ti,ab,kw,kf. & 0 & $\begin{array}{l}\text { Remove - never found } \\
\text { a reference }\end{array}$ \\
\hline $\begin{array}{l}\text { Included in v8 } \\
\text { (April 2020) }\end{array}$ & NcovChina*.ti,ab,kw,kf. & 0 & $\begin{array}{l}\text { Remove - never found } \\
\text { a reference }\end{array}$ \\
\hline $\begin{array}{l}\text { Included in v8 } \\
\text { (April 2020) }\end{array}$ & NcovChinese*.ti,ab,kw,kf. & 0 & $\begin{array}{l}\text { Remove - never found } \\
\text { a reference }\end{array}$ \\
\hline $\begin{array}{l}\text { Included in v8 } \\
\text { (April 2020) }\end{array}$ & SARS2.ti,ab,kw,kf. & 9 & $\begin{array}{l}\text { Retain - finds } \\
\text { references }\end{array}$ \\
\hline $\begin{array}{l}\text { Included in v8 } \\
\text { (April 2020) }\end{array}$ & "SARS-2".ti,ab,kw,kf. & 30 & $\begin{array}{l}\text { Retain - finds } \\
\text { references }\end{array}$ \\
\hline $\begin{array}{l}\text { Included in v8 } \\
\text { (April 2020) }\end{array}$ & SARScoronavirus2.ti,ab,kw,kf. & 0 & $\begin{array}{l}\text { Retain -not found a } \\
\text { reference but variant } \\
\text { of a term that has }\end{array}$ \\
\hline $\begin{array}{l}\text { Included in v8 } \\
\text { (April 2020) }\end{array}$ & "SARS-coronavirus-2".ti,ab,kw,kf. & 34 & $\begin{array}{l}\text { Retain - finds } \\
\text { references }\end{array}$ \\
\hline $\begin{array}{l}\text { Included in v8 } \\
\text { (April 2020) }\end{array}$ & "SARScoronavirus 2".ti,ab,kw,kf. & 0 & $\begin{array}{l}\text { Retain -not found a } \\
\text { reference but variant } \\
\text { of a term that has }\end{array}$ \\
\hline $\begin{array}{l}\text { Included in v8 } \\
\text { (April 2020) }\end{array}$ & "SARS coronavirus2".ti,ab,kw,kf. & 1 & $\begin{array}{l}\text { Retain - finds } \\
\text { references }\end{array}$ \\
\hline $\begin{array}{l}\text { Included in v8 } \\
\text { (April 2020) }\end{array}$ & SARScoronovirus2.ti, ab,kw,kf. & 0 & $\begin{array}{l}\text { Remove - never found } \\
\text { a reference }\end{array}$ \\
\hline
\end{tabular}


medRxiv preprint doi: https://doi.org/10.1101/2021.06.11.21258749; this version posted June 14, 2021. The copyright holder for this preprint (which was not certified by peer review) is the author/funder, who has granted medRxiv a license to display the preprint in perpetuity.

It is made available under a CC-BY 4.0 International license .

\begin{tabular}{|c|c|c|c|}
\hline $\begin{array}{l}\text { Included in v8 } \\
\text { (April 2020) }\end{array}$ & "SARS-coronovirus-2".ti,ab,kw,kf. & 0 & $\begin{array}{l}\text { Remove - never found } \\
\text { a reference }\end{array}$ \\
\hline $\begin{array}{l}\text { Included in v8 } \\
\text { (April 2020) }\end{array}$ & "SARScoronovirus 2".ti,ab,kw,kf. & 0 & $\begin{array}{l}\text { Remove - never found } \\
\text { a reference }\end{array}$ \\
\hline $\begin{array}{l}\text { Included in v8 } \\
\text { (April 2020) }\end{array}$ & "SARS coronovirus2".ti,ab,kw & 0 & $\begin{array}{l}\text { Remove - never found } \\
\text { a reference }\end{array}$ \\
\hline $\begin{array}{l}\text { Identified May } \\
2020\end{array}$ & CoV2*.ti,ab,kw,kf. & 292 & $\begin{array}{l}\text { Reject }-273 \text { already } \\
\text { found by } v 8 \text {. The } \\
\text { remaining } 19 \text { are not } \\
\text { relevant }\end{array}$ \\
\hline $\begin{array}{l}\text { Identified May } \\
2020\end{array}$ & Betacoronavirus*.ti,ab,kw,kf. & 306 & $\begin{array}{l}\text { Reject }-303 \text { already } \\
\text { found by } 8 \text {. The } \\
\text { remaining } 3 \text { are not } \\
\text { relevant }\end{array}$ \\
\hline $\begin{array}{l}\text { Identified May } \\
2020\end{array}$ & Betacoronovirus*.ti,ab,kw,kf. & 1 & $\begin{array}{l}\text { Reject - } 1 \text { paper not } \\
\text { relevant }\end{array}$ \\
\hline $\begin{array}{l}\text { Identified May } \\
2020\end{array}$ & "wuhan virus*".ti,ab,kw,kf. & 6 & $\begin{array}{l}\text { Reject }-4 \text { already } \\
\text { found by v8. Two } \\
\text { unique papers ( } 1 \text { news } \\
\text { item) from Jan } 2020 \\
\text { before WHO naming } \\
\text { convention }\end{array}$ \\
\hline $\begin{array}{l}\text { Identified May } \\
2020\end{array}$ & "SARSCoVID2*".ti,ab,kw,kf. & 0 & $\begin{array}{l}\text { Reject - never found a } \\
\text { reference }\end{array}$ \\
\hline $\begin{array}{l}\text { Identified May } \\
2020\end{array}$ & "SARS-CoVID2*".ti,ab,kw,kf. & 0 & $\begin{array}{l}\text { Reject - never found a } \\
\text { reference }\end{array}$ \\
\hline $\begin{array}{l}\text { Identified May } \\
2020\end{array}$ & SARSCovID19*.ti,ab,kw,kf. & 0 & $\begin{array}{l}\text { Reject - never found a } \\
\text { reference }\end{array}$ \\
\hline $\begin{array}{l}\text { Identified May } \\
2020\end{array}$ & "SARS-CovID19*".ti,ab,kw,kf. & 0 & $\begin{array}{l}\text { Reject - never found a } \\
\text { reference }\end{array}$ \\
\hline $\begin{array}{l}\text { Identified May } \\
2020\end{array}$ & "SARSCovID-19*".ti,ab,kw,kf. & 0 & $\begin{array}{l}\text { Reject - never found a } \\
\text { reference }\end{array}$ \\
\hline $\begin{array}{l}\text { Identified May } \\
2020\end{array}$ & SARSCovID2019*.ti,ab,kw,kf. & 0 & $\begin{array}{l}\text { Reject - never found a } \\
\text { reference }\end{array}$ \\
\hline $\begin{array}{l}\text { Identified May } \\
2020\end{array}$ & "SARS-CovID2019*".ti,ab,kw,kf. & 0 & $\begin{array}{l}\text { Reject - never found a } \\
\text { reference }\end{array}$ \\
\hline $\begin{array}{l}\text { Identified May } \\
2020\end{array}$ & "SARSCovID-2019*".ti,ab,kw,kf. & 0 & $\begin{array}{l}\text { Reject - never found a } \\
\text { reference }\end{array}$ \\
\hline $\begin{array}{l}\text { Identified May } \\
2020\end{array}$ & "SARS-CovID-2019*".ti,ab,kw,kf. & 0 & $\begin{array}{l}\text { Reject - never found a } \\
\text { reference }\end{array}$ \\
\hline $\begin{array}{l}\text { Identified May } \\
2020\end{array}$ & "SARS-CovID-19*".ti,ab,kw,kf. & 15 & $\begin{array}{l}\text { Reject - } 15 \text { already } \\
\text { found by v } 8 \text { and WHO } \\
\text { naming convention } \\
\text { now in place }\end{array}$ \\
\hline
\end{tabular}




\section{Appendix D. Search strategy options for NICE COVID-19}

\section{Appendix D. Strategy A. Original NICE search strategy v9 (June 2020)}

\section{MEDLINE}

\begin{tabular}{|c|c|c|}
\hline $\begin{array}{l}\text { Categorisation } \\
\text { from Figure } 1\end{array}$ & $\begin{array}{c}\text { Line } \\
\text { number }\end{array}$ & Search terms \\
\hline$x$ & 1 & exp coronavirus/ \\
\hline$x$ & 2 & exp Coronavirus Infections/ \\
\hline High & 3 & (corona* adj1 (virus* or viral*)).ti,ab,kw,kf. \\
\hline Zero & 4 & (corona* adj1 virinae*).ti,ab,kw,kf. \\
\hline Low & 5 & (corono* adj1 (virus* or viral*)).ti,ab,kw,kf. \\
\hline Zero & 6 & (corono* adj1 virinae*).ti,ab,kw,kf. \\
\hline Critical & 7 & coronavirus*.ti,ab,kw,kf. \\
\hline Low & 8 & coronovirus*.ti,ab,kw,kf. \\
\hline Low & 9 & coronavirinae*.ti,ab,kw,kf. \\
\hline Zero & 10 & coronovirinae*.ti,ab,kw,kf. \\
\hline Medium & 11 & CoV.ti,ab,kw,kf. \\
\hline Medium & 12 & $\begin{array}{l}\text { ("2019-nCoV*" or 2019nCoV* or "19-nCoV*" or 19nCoV* or } \\
\text { nCoV2019* or "nCoV-2019*" or nCoV19* or "nCoV- } \\
\text { 19*").ti,ab,kw,kf. }\end{array}$ \\
\hline Critical & 13 & ("COVID-19*" or COVID19* or "COVID-2019*" or covid).ti,ab,kw,kf. \\
\hline Low & 14 & $\begin{array}{l}\text { ("HCoV-19*" or HCoV19* or "HCoV-2019*" or } \\
\text { HCoV2019*).ti,ab,kw,kf. }\end{array}$ \\
\hline Medium & 15 & ("2019 novel*" or Ncov* or "n-cov").ti,ab,kw,kf. \\
\hline High & 16 & $\begin{array}{l}\text { ("SARS-CoV-2*" or "SARSCoV-2*" or "SARSCoV2*" or "SARS- } \\
\text { CoV2*").ti,ab,kw,kf. }\end{array}$ \\
\hline Low & 17 & $\begin{array}{l}\text { (SARSCov19* or "SARS-Cov19*" or "SARSCov-19*" or "SARS-Cov- } \\
\text { 19*" or SARSCov2019* or "SARS-Cov2019*" or "SARSCov-2019*" } \\
\text { or "SARS-Cov-2019*").ti,ab,kw,kf. }\end{array}$ \\
\hline Low & 18 & (SARS2* or "SARS-2*").ti, ab,kw,kf. \\
\hline Low & 19 & (SARScoronavirus $2 *$ or "SARS-coronavirus-2*").ti,ab,kw,kf. \\
\hline Zero & 20 & ("SARScoronovirus 2*" or "SARS coronovirus2*").ti,ab,kw,kf. \\
\hline Low & 21 & $\begin{array}{l}\text { (respiratory* adj2 (symptom* or disease* or illness* or condition*) } \\
\text { adj5 (Wuhan* or Hubei* or China* or Chinese* or } \\
\text { Huanan*)).ti,ab,kw,kf. }\end{array}$ \\
\hline Low & 22 & $\begin{array}{l}\text { (("seafood market*" or "food market*") adj10 (Wuhan* or Hubei* } \\
\text { or China* or Chinese* or Huanan*)).ti,ab,kw,kf. }\end{array}$ \\
\hline Low & 23 & $\begin{array}{l}\text { (pneumonia* adj3 (Wuhan* or Hubei* or China* or Chinese* or } \\
\text { Huanan*)).ti, ab,kw,kf. }\end{array}$ \\
\hline Low & 24 & $\begin{array}{l}\text { ((outbreak* or wildlife* or pandemic* or epidemic*) adj1 (Wuhan* } \\
\text { or Hubei* or China* or Chinese* or Huanan*)).ti,ab,kw,kf. }\end{array}$ \\
\hline Medium & 25 & "severe acute respiratory syndrome*".ti,ab,kw,kf. \\
\hline$x$ & 26 & or $/ 1-25$ \\
\hline
\end{tabular}




\section{Embase}

\begin{tabular}{|c|c|c|}
\hline $\begin{array}{l}\text { Categorisation } \\
\text { from Figure } 1\end{array}$ & $\begin{array}{c}\text { Line } \\
\text { number }\end{array}$ & Search terms \\
\hline$x$ & 1 & exp Coronavirinae/ \\
\hline$x$ & 2 & exp Coronavirus infection/ \\
\hline $\mathrm{x}$ & 3 & $\begin{array}{l}\text { ("coronavirus disease 2019" or "severe acute respiratory syndrome } \\
\text { coronavirus 2").sh,dj. }\end{array}$ \\
\hline High & 4 & (corona* adj1 (virus* or viral*)).ti,ab,kw \\
\hline Zero & 5 & (corona* adj1 virinae*).ti,ab,kw \\
\hline Low & 6 & (corono* adj1 (virus* or viral*)).ti,ab,kw \\
\hline Zero & 7 & (corono* adj1 virinae*).ti,ab,kw \\
\hline Critical & 8 & coronavirus*.ti,ab,kw \\
\hline Low & 9 & coronovirus*.ti,ab,kw \\
\hline Low & 10 & coronavirinae*.ti,ab,kw \\
\hline Zero & 11 & coronovirinae*.ti,ab,kw \\
\hline Medium & 12 & CoV.ti,ab,kw \\
\hline Medium & 13 & $\begin{array}{l}\text { ("2019-nCoV*" or } 2019 n C o V * \text { or "19-nCoV*" or } 19 n \mathrm{CoV}^{*} \text { or } \\
\text { nCoV2019* or "nCoV-2019*" or nCoV19* or "nCoV-19*").ti,ab,kw }\end{array}$ \\
\hline Critical & 14 & ("COVID-19*" or COVID19* or "COVID-2019*" or covid).ti,ab,kw \\
\hline Low & 15 & $\begin{array}{l}\text { ("HCoV-19*" or HCoV19* or "HCoV-2019*" or } \\
\text { HCoV2019*).ti,ab,kw }\end{array}$ \\
\hline Medium & 16 & ("2019 novel*" or Ncov* or "n-cov").ti,ab,kw \\
\hline High & 17 & $\begin{array}{l}\text { ("SARS-CoV-2*" or "SARSCoV-2*" or "SARSCoV2*" or "SARS- } \\
\text { CoV2*").ti,ab,kw }\end{array}$ \\
\hline Low & 18 & $\begin{array}{l}\text { (SARSCov19* or "SARS-Cov19*" or "SARSCov-19*" or "SARS-Cov- } \\
\text { 19*" or SARSCov2019* or "SARS-Cov2019*" or "SARSCov-2019*" } \\
\text { or "SARS-Cov-2019*").ti,ab,kw }\end{array}$ \\
\hline Low & 19 & (SARS2* or "SARS-2*").ti,ab,kw \\
\hline Low & 20 & (SARScoronavirus2* or "SARS-coronavirus-2*").ti,ab,kw \\
\hline Zero & 21 & ("SARScoronovirus $2 *$ " or "SARS coronovirus $2 *$ ").ti,ab,kw \\
\hline Low & 22 & $\begin{array}{l}\text { (respiratory* adj2 (symptom* or disease* or illness* or condition*) } \\
\text { adj5 (Wuhan* or Hubei* or China* or Chinese* or } \\
\text { Huanan*)).ti,ab,kw }\end{array}$ \\
\hline Low & 23 & $\begin{array}{l}\text { (("seafood market*" or "food market*") adj10 (Wuhan* or Hubei* } \\
\text { or China* or Chinese* or Huanan*)).ti,ab,kw }\end{array}$ \\
\hline Low & 24 & $\begin{array}{l}\text { (pneumonia* adj3 (Wuhan* or Hubei* or China* or Chinese* or } \\
\text { Huanan*)).ti,ab,kw }\end{array}$ \\
\hline Low & 25 & $\begin{array}{l}\text { ((outbreak* or wildlife* or pandemic* or epidemic*) adj1 (Wuhan* } \\
\text { or Hubei* or China* or Chinese* or Huanan*)).ti,ab,kw }\end{array}$ \\
\hline Medium & 26 & "severe acute respiratory syndrome*".ti,ab,kw \\
\hline$x$ & 27 & or/1-26 \\
\hline
\end{tabular}




\section{Appendix D. Strategy B. Retain Low lines, Remove Zero lines}

\section{MEDLINE}

\begin{tabular}{|c|c|c|}
\hline $\begin{array}{l}\text { Categorisation } \\
\text { from Figure } 1\end{array}$ & $\begin{array}{l}\text { Line } \\
\text { number }\end{array}$ & Search terms \\
\hline$x$ & 1 & exp coronavirus/ \\
\hline$x$ & 2 & exp Coronavirus Infections/ \\
\hline High & 3 & (corona* adj1 (virus* or viral*)).ti,ab,kw,kf. \\
\hline Low & 4 & (corono* adj1 (virus* or viral*)).ti,ab,kw,kf. \\
\hline Critical & 5 & coronavirus*.ti,ab,kw,kf. \\
\hline Low & 6 & coronovirus*.ti,ab,kw,kf. \\
\hline Low & 7 & coronavirinae*.ti,ab,kw,kf. \\
\hline Medium & 8 & CoV.ti,ab,kw,kf. \\
\hline Medium & 9 & $\begin{array}{l}\text { ("2019-nCoV*" or 2019nCoV* or "19-nCoV*" or 19nCoV* or } \\
\text { nCoV2019* or "nCoV-2019*" or nCoV19* or "nCoV- } \\
19 * ") . t i, a b, k w, k f .\end{array}$ \\
\hline Critical & 10 & $\begin{array}{l}\text { ("COVID-19*" or COVID19* or "COVID-2019*" or } \\
\text { covid).ti,ab,kw,kf. }\end{array}$ \\
\hline Low & 11 & $\begin{array}{l}\text { ("HCoV-19*" or HCoV19* or "HCoV-2019*" or } \\
\text { HCoV2019*).ti,ab,kw,kf. }\end{array}$ \\
\hline Medium & 12 & ("2019 novel*" or Ncov* or "n-cov").ti,ab,kw,kf. \\
\hline High & 13 & $\begin{array}{l}\text { ("SARS-CoV-2*" or "SARSCoV-2*" or "SARSCoV2*" or "SARS- } \\
\text { CoV2*").ti,ab,kw,kf. }\end{array}$ \\
\hline Low & 14 & $\begin{array}{l}\text { (SARSCov19* or "SARS-Cov19*" or "SARSCov-19*" or "SARS- } \\
\text { Cov-19*" or SARSCov2019* or "SARS-Cov2019*" or } \\
\text { "SARSCov-2019*" or "SARS-Cov-2019*").ti,ab,kw,kf. }\end{array}$ \\
\hline Low & 15 & (SARS2* or "SARS-2*").ti,ab,kw,kf. \\
\hline Low & 16 & (SARScoronavirus2* or "SARS-coronavirus-2*").ti,ab,kw,kf. \\
\hline Low & 17 & $\begin{array}{l}\text { (respiratory* adj2 (symptom* or disease* or illness* or } \\
\text { condition*) adj5 (Wuhan* or Hubei* or China* or Chinese* or } \\
\text { Huanan*)).ti,ab,kw,kf. }\end{array}$ \\
\hline Low & 18 & $\begin{array}{l}\text { (("seafood market*" or "food market*") adj10 (Wuhan* or } \\
\text { Hubei* or China* or Chinese* or Huanan*)).ti,ab,kw,kf. }\end{array}$ \\
\hline Low & 19 & $\begin{array}{l}\text { (pneumonia* adj3 (Wuhan* or Hubei* or China* or Chinese* } \\
\text { or Huanan*)).ti,ab,kw,kf. }\end{array}$ \\
\hline Low & 20 & $\begin{array}{l}\text { ((outbreak* or wildlife* or pandemic* or epidemic*) adj1 } \\
\text { (Wuhan* or Hubei* or China* or Chinese* or } \\
\text { Huanan*)).ti,ab,kw,kf. }\end{array}$ \\
\hline Medium & 21 & "severe acute respiratory syndrome*".ti,ab,kw,kf. \\
\hline$x$ & 22 & or/1-21 \\
\hline
\end{tabular}


medRxiv preprint doi: https://doi.org/10.1101/2021.06.11.21258749; this version posted June 14, 2021. The copyright holder for this preprint (which was not certified by peer review) is the author/funder, who has granted medRxiv a license to display the preprint in perpetuity.

It is made available under a CC-BY 4.0 International license .

\section{Embase}

\begin{tabular}{|c|c|c|}
\hline $\begin{array}{l}\text { Categorisation } \\
\text { from Figure } 1\end{array}$ & $\begin{array}{l}\text { Line } \\
\text { number }\end{array}$ & Search terms \\
\hline$x$ & 1 & exp Coronavirinae/ \\
\hline$x$ & 2 & exp Coronavirus infection/ \\
\hline $\mathrm{x}$ & 3 & $\begin{array}{l}\text { ("coronavirus disease } 2019 \text { " or "severe acute respiratory } \\
\text { syndrome coronavirus 2").sh,dj. }\end{array}$ \\
\hline High & 4 & (corona* adj1 (virus* or viral*)).ti,ab,kw \\
\hline Low & 5 & (corono* adj1 (virus* or viral*)).ti,ab,kw \\
\hline Critical & 6 & coronavirus*.ti,ab,kw \\
\hline Low & 7 & coronovirus*.ti,ab,kw \\
\hline Low & 8 & coronavirinae*.ti,ab,kw \\
\hline Medium & 9 & CoV.ti,ab,kw \\
\hline Medium & 10 & $\begin{array}{l}\text { ("2019-nCoV*" or 2019nCoV* or "19-nCoV*" or 19nCoV* or } \\
\text { nCoV2019* or "nCoV-2019*" or nCoV19* or "nCoV- } \\
19 * ") . t i, a b, k w\end{array}$ \\
\hline Critical & 11 & $\begin{array}{l}\text { ("COVID-19*" or COVID19* or "COVID-2019*" or } \\
\text { covid).ti,ab,kw }\end{array}$ \\
\hline Low & 12 & $\begin{array}{l}\text { ("HCoV-19*" or HCoV19* or "HCoV-2019*" or } \\
\text { HCoV2019*).ti,ab,kw }\end{array}$ \\
\hline Medium & 13 & ("2019 novel*" or Ncov* or "n-cov").ti,ab,kw \\
\hline High & 14 & $\begin{array}{l}\text { ("SARS-CoV-2*" or "SARSCoV-2*" or "SARSCoV2*" or "SARS- } \\
\text { CoV2*").ti,ab,kw }\end{array}$ \\
\hline Low & 15 & $\begin{array}{l}\text { (SARSCov19* or "SARS-Cov19*" or "SARSCov-19*" or "SARS- } \\
\text { Cov-19*" or SARSCov2019* or "SARS-Cov2019*" or } \\
\text { "SARSCov-2019*" or "SARS-Cov-2019*").ti,ab,kw }\end{array}$ \\
\hline Low & 16 & (SARS2* or "SARS-2*").ti,ab,kw \\
\hline Low & 17 & (SARScoronavirus2* or "SARS-coronavirus-2*").ti,ab,kw \\
\hline Low & 18 & $\begin{array}{l}\text { (respiratory* adj2 (symptom* or disease* or illness* or } \\
\text { condition*) adj5 (Wuhan* or Hubei* or China* or Chinese* or } \\
\text { Huanan*)).ti,ab,kw }\end{array}$ \\
\hline Low & 19 & $\begin{array}{l}\text { (("seafood market*" or "food market*") adj10 (Wuhan* or } \\
\text { Hubei* or China* or Chinese* or Huanan*)).ti,ab,kw }\end{array}$ \\
\hline Low & 20 & $\begin{array}{l}\text { (pneumonia* adj3 (Wuhan* or Hubei* or China* or Chinese* } \\
\text { or Huanan*)).ti,ab,kw }\end{array}$ \\
\hline Low & 21 & $\begin{array}{l}\text { ((outbreak* or wildlife* or pandemic* or epidemic*) adj1 } \\
\text { (Wuhan* or Hubei* or China* or Chinese* or } \\
\text { Huanan*)).ti,ab,kw }\end{array}$ \\
\hline Medium & 22 & "severe acute respiratory syndrome*".ti,ab,kw \\
\hline$x$ & 23 & or/1-22 \\
\hline
\end{tabular}




\section{Appendix D. Strategy C. Retain Medium lines, Remove Zero and Low lines}

\section{MEDLINE}

\begin{tabular}{|c|c|c|}
\hline $\begin{array}{l}\text { Categorisation } \\
\text { from Figure } 1\end{array}$ & $\begin{array}{l}\text { Line } \\
\text { number }\end{array}$ & Search terms \\
\hline$x$ & 1 & exp coronavirus/ \\
\hline$x$ & 2 & exp Coronavirus Infections/ \\
\hline High & 3 & (corona* adj1 (virus* or viral*)).ti,ab,kw,kf. \\
\hline Critical & 4 & coronavirus*.ti,ab,kw,kf. \\
\hline Medium & 5 & CoV.ti,ab,kw,kf. \\
\hline Medium & 6 & $\begin{array}{l}\text { ("2019-nCoV*" or } 2019 n C o V^{*} \text { or "19-nCoV*" or } 19 n \mathrm{CoV}^{*} \text { or } \\
\text { nCoV2019* or "nCoV-2019*" or nCoV19* or "nCoV- } \\
19 * ") . t i, a b, k w, k f .\end{array}$ \\
\hline Critical & 7 & $\begin{array}{l}\text { ("COVID-19*" or COVID19* or "COVID-2019*" or } \\
\text { covid).ti,ab,kw,kf. }\end{array}$ \\
\hline Medium & 8 & ("2019 novel*" or Ncov* or "n-cov").ti,ab,kw,kf. \\
\hline High & 9 & $\begin{array}{l}\text { ("SARS-CoV-2*" or "SARSCoV-2*" or "SARSCoV2*" or "SARS- } \\
\text { CoV2*").ti,ab,kw,kf. }\end{array}$ \\
\hline Medium & 10 & "severe acute respiratory syndrome*".ti,ab,kw,kf. \\
\hline$x$ & 11 & or/1-10 \\
\hline
\end{tabular}

\section{Embase}

\begin{tabular}{|c|c|c|}
\hline $\begin{array}{l}\text { Categorisation } \\
\text { from Figure } 1\end{array}$ & $\begin{array}{l}\text { Line } \\
\text { number }\end{array}$ & Search terms \\
\hline$x$ & 1 & exp Coronavirinae/ \\
\hline$x$ & 2 & exp Coronavirus infection/ \\
\hline $\mathrm{x}$ & 3 & $\begin{array}{l}\text { ("coronavirus disease } 2019 \text { " or "severe acute respiratory } \\
\text { syndrome coronavirus 2").sh,dj. }\end{array}$ \\
\hline High & 4 & (corona* adj1 (virus* or viral*)).ti,ab,kw \\
\hline Critical & 5 & coronavirus*.ti,ab,kw,kf. \\
\hline Medium & 6 & CoV.ti,ab,kw \\
\hline Medium & 7 & $\begin{array}{l}\text { ("2019-nCoV*" or } 2019 n C o V * \text { or "19-nCoV*" or } 19 n \mathrm{CoV}^{*} \text { or } \\
\text { nCoV2019* or "nCoV-2019*" or nCoV19* or "nCoV- } \\
19^{* ") . t i, a b, k w}\end{array}$ \\
\hline Critical & 8 & $\begin{array}{l}\text { ("COVID-19*" or COVID19* or "COVID-2019*" or } \\
\text { covid).ti,ab,kw }\end{array}$ \\
\hline Medium & 9 & ("2019 novel*" or Ncov* or "n-cov").ti,ab,kw \\
\hline High & 10 & $\begin{array}{l}\text { ("SARS-CoV-2*" or "SARSCoV-2*" or "SARSCoV2*" or "SARS- } \\
\text { CoV2*").ti,ab,kw }\end{array}$ \\
\hline Medium & 11 & "severe acute respiratory syndrome*".ti,ab,kw \\
\hline$x$ & 12 & or/1-11 \\
\hline
\end{tabular}




\section{Appendix D. Strategy D. Retain High lines, Remove Medium lines}

\section{MEDLINE}

\begin{tabular}{|l|l|l|}
\hline $\begin{array}{l}\text { Categorisation } \\
\text { from Figure 1 }\end{array}$ & $\begin{array}{l}\text { Line } \\
\text { number }\end{array}$ & Search terms \\
\hline $\mathrm{x}$ & 1 & exp coronavirus/ \\
\hline $\mathrm{x}$ & 2 & exp Coronavirus Infections/ \\
\hline High & 3 & (corona* adj1 (virus* or viral*)).ti,ab,kw,kf. \\
\hline Critical & 4 & coronavirus*.ti,ab,kw,kf. \\
\hline Critical & 5 & $\begin{array}{l}\text { ("COVID-19*" or COVID19* or "COVID-2019*" or } \\
\text { covid).ti,ab,kw,kf. }\end{array}$ \\
\hline High & 6 & $\begin{array}{l}\text { ("SARS-CoV-2*" or "SARSCoV-2*" or "SARSCoV2 } \\
\text { CoV2 }{ }^{*} \text { ").ti,ab,kw, or "SARS- }\end{array}$ \\
\hline $\mathrm{x}$ & 7 & \begin{tabular}{l} 
or/1-6 \\
\hline
\end{tabular}
\end{tabular}

\section{Embase}

\begin{tabular}{|l|l|l|}
\hline $\begin{array}{l}\text { Categorisation } \\
\text { from Figure } 1\end{array}$ & $\begin{array}{l}\text { Line } \\
\text { number }\end{array}$ & Search terms \\
\hline $\mathrm{x}$ & 1 & exp Coronavirinae/ \\
\hline $\mathrm{x}$ & 2 & exp Coronavirus infection/ \\
\hline $\mathrm{x}$ & 3 & $\begin{array}{l}\text { ("coronavirus disease 2019" or "severe acute respiratory } \\
\text { syndrome coronavirus 2").sh,dj. }\end{array}$ \\
\hline High & 4 & (corona* adj1 (virus* or viral*)).ti,ab,kw \\
\hline Critical & 5 & coronavirus*.ti,ab,kw \\
\hline Critical & 6 & $\begin{array}{l}\text { ("COVID-19*" or COVID19* or "COVID-2019*" or } \\
\text { covid).ti,ab,kw }\end{array}$ \\
\hline High & 7 & $\begin{array}{l}\text { ("SARS-CoV-2*" or "SARSCoV-2*" or "SARSCoV2*" or "SARS- } \\
\text { CoV2*").ti,ab,kw }\end{array}$ \\
\hline $\mathrm{x}$ & 8 & or/1-7 \\
\hline
\end{tabular}


medRxiv preprint doi: https://doi.org/10.1101/2021.06.11.21258749; this version posted June 14, 2021. The copyright holder for this preprint (which was not certified by peer review) is the author/funder, who has granted medRxiv a license to display the preprint in perpetuity.

It is made available under a CC-BY 4.0 International license.

\section{Appendix D. Strategy E. Retain Critical lines, Remove all other lines}

\section{MEDLINE}

\begin{tabular}{|l|l|l|}
\hline $\begin{array}{l}\text { Categorisation } \\
\text { from Figure 1 }\end{array}$ & $\begin{array}{l}\text { Line } \\
\text { number }\end{array}$ & Search terms \\
\hline $\mathrm{x}$ & 1 & exp coronavirus/ \\
\hline $\mathrm{x}$ & 2 & exp Coronavirus Infections/ \\
\hline Critical & 3 & coronavirus*.ti,ab,kw,kf. \\
\hline Critical & 4 & $\begin{array}{l}\text { ("COVID-19*" or COVID19* or "COVID-2019*" or } \\
\text { covid).ti,ab,kw,kf. }\end{array}$ \\
\hline $\mathrm{x}$ & 5 & or/1-4 \\
\hline
\end{tabular}

\section{Embase}

\begin{tabular}{|c|c|c|}
\hline $\begin{array}{l}\text { Categorisation } \\
\text { from Figure } 1\end{array}$ & $\begin{array}{l}\text { Line } \\
\text { number }\end{array}$ & Search terms \\
\hline$x$ & 1 & exp Coronavirinae/ \\
\hline$x$ & 2 & exp Coronavirus infection/ \\
\hline $\mathrm{x}$ & 3 & $\begin{array}{l}\text { ("coronavirus disease } 2019 \text { " or "severe acute respiratory } \\
\text { syndrome coronavirus } 2 " \text { ").sh, dj. }\end{array}$ \\
\hline Critical & 4 & coronavirus*.ti,ab,kw,kf. \\
\hline Critical & 5 & $\begin{array}{l}\text { ("COVID-19*" or COVID19* or "COVID-2019*" or } \\
\text { covid).ti,ab,kw }\end{array}$ \\
\hline$x$ & 6 & or/1-5 \\
\hline
\end{tabular}

